\title{
DONAṬII DIN BUNURILE PĂRINTELUI NEBUN - O PRIVIRE ISTORICĂ
}

\begin{abstract}
Gifts from the insane parent's property - a historical perspective. In the postclassical Roman legal system, the paternal consent was still mandatory for the legitimacy of a marriage. The parent was also obliged by the Justinian law, to constitute a dowry to his daughter or an ante-nuptial donation for his son. However, what would happen if he went insane? An insane person could not consent either to the marriage, either to the donations that accompanied the legal union between husband and wife because he was considered without any will. Justinian intervened and permitted those marriages and the constitution of dowries and ante-nuptial donations, without paternal consent. He gave a constitution that permitted the family and the legal guardian of the insane to act on behalf of the insane parent, under the supervision of a Roman magistrate. That legal measure was used to justify and legitimate a similar legal measure, inserted into the French Civil code of 1804. The same disposition was imported from the French legislation and implemented by the Romanian Civil code of 1864. It has also reverberated in a Romanian civil code of 1939 (never into force). In this article, we will try to prove the harmonizing aspect of the Justinian constitution and the unlikely rebirth of a comparable legal measure in the modern era.
\end{abstract}

Keywords: dowry, donation, incapacity, insanity, interdiction, tutor, tutorship, curator, curatorship, consent, Roman law.

Rezumat: În perioada dreptului roman post-clasic, consimțământul părintelui la căsătoria copiilor săi a fost în continuare considerat obligatoriu pentru legitimitatea căsătoriei. Constituirea unei dote, sau a unei donații antenupțiale, a devenit obligatorie pentru părinte, sub domnia lui lustinian. Dar ce se întâmpla atunci când părintele devenea nebun? O persoană nebună nu putea consimți nici la căsătorie și nici nu putea constitui dota sau donațiile ce însoțeau căsătoria romană, întrucât nu avea voință. lustinian va interveni și va permite aceste căsătorii și de asemenea constituirea unei dote sau a unei donații antenupțiale, fără consimțământul părintelui nebun. Acesta a stabilit, că familia și curatorul persoanei nebune vor putea acționa pentru acesta, sub supravegherea unui magistrat. Măsura legală a fost utilizată pentru a justifica și legitima o dispoziție similară, inserată în Codului civil francez de la 1804 in art. 511 (nr. articolului anterior reformei din 1968). Textul francez a fost preluat 
de Codul civil român de la 1864. Aceasta a reapărut, într-o formă similară, și în Codul civil român de la 1939 (ce nu a intrat niciodată în vigoare). În cadrul acestui articol, vom încerca să dovedim aspectul armonizant al dispoziției introduse de lustinian și caracterul improbabil al funcționării acesteia într-o legislație civilă contemporană.

Cuvinte-cheie: dotă, donații, incapacitate, nebun, interdicție, tutore, tutelă, curator, curatelă, consimțământ, drept roman.

În secolul al V-lea d.Hr., împăratul lustinian va lămuri, prin intermediul unei Constituții imperiale, o problemă a timpului său: posibilitatea căsătoriei copiilor unei persoane nebune. Totodată el va dispune cum anume se va constitui, cu această ocazie, dota și donațiile antenupțiale ${ }^{1}$ pentru acești descendenți. Textele dreptului roman au fost utilizate ulterior, de comentatorii Codului civil francez de la 1804, pentru a justifica și legitima o dispoziție franceză cuprinsă în art. 511 al Cod civil francez (nr. articolului anterior reformei din 1968)2.

Vechiul Cod civil român de la $1864^{3}$ va prelua din Codul civil francez textul art. $511^{4}$ în textul art. $456^{5}$ (text ce va fi abrogat prin Decretul nr. 32/1954). O reglementare similară se va regăsi și în auto-intitulatul Cod civil „Carol al II-lea”, , din 1939 în art. 420, devenit, după modificarea din $1940^{7}$, art. 528 ${ }^{8}$. Acest din urmă act normativ nu a intrat vreodată în vigoare, însă și el stă mărturie aceleiași invenții și utilități purtate de norma juridică în cauză.

Articolul de față dorește să prezinte contextul în care reglementarea împăratului lustinian a luat ființă, în dreptul roman (1) pentru ca apoi să urmărească preluarea sa în Codul civil francez de la 1804 (2), iar la final să proclame imposibilitatea oricărei aplicări a unei reglementări similare, în contextul juridic actual (3).

\section{(1) Dreptul Roman 9}

O succintă expunere a regulilor în materia ocrotirii ${ }^{10}$ persoanelor în dreptul roman este necesară pentru înțelegerea climatului în care împăratul lustinian va permite donațiile către descendenții unei persoane care își pierduse rațiunea și era plasată sub una dintre măsurile de protecție romane.

Câteva repere asupra tutelei și curatelei romane ne vor furniza o viziune asupra naturii acestora și asupra persoanelor care făceau obiectul unor astfel de măsuri (i) pentru ca apoi, abordarea consimțământului patern la căsătoria copiilor săi (ii) și prezentarea succintă a evoluției dotei și a donațiilor propter-nupțiale (iii) ne vor permite să înțelegem contextul adoptării reglementării cu privire la donațiile din bunurile părintelui nebun (iv). De-a lungul acestui periplu, vom reliefa, acolo unde dispunem de informațiile necesare, o abordare cronologică a soluțiilor dreptului roman prin apelul la perioadele istorice ale acestuia: perioada arhaică - a dreptului quiritar sau a vechiului drept roman (sec. VIII î.Hr. mijlocul secolului IV. î.Hr.) ${ }^{11}$, perioada preclasică sau a republicii romane naționale (sec. IV sec. I î.Hr., an 27 î.Hr. $)^{12}$, perioada clasică, a republicii romane universale sau a principatului ${ }^{13}$ 
(ultimii ani ai sec. I î.Hr. - III d.Hr. an 284 d.Hr.) ${ }^{14}$ și perioada post-clasică ${ }^{15}$ a imperiului roman sau a dominatului ${ }^{16}$ (sec. IV-VI d.Hr., an 656 d.Hr. $)^{17}$

\section{(i.) Curatela și tutela romană}

În cele ce urmează vom prezenta, pe scurt, cine au fost destinatarii măsurilor de ocrotire în dreptul roman, prin ce se diferențiau tutela de curatelă și de interdicția prodigilor, precum și care era consecința pronunțării unui decret de plasare sub curatelă a nebunilor.

\section{a) Sfera persoanelor ocrotite}

Măsurile au vizat doar pe aceia ce erau deopotrivă liberi (aveau status libertatis), cetățeni (aveau status civitatis) și erau sui iuris, neaflându-se sub puterea altcuiva ${ }^{18}$. Sui iuris erau fie femeile ${ }^{19}$, fie bărbații capi ai unei familii (pater familias).

Pater, din construcția pater familias, nu definea descendența, pentru care romanii aveau cuvântul parens sau genitor, ci autoritatea ${ }^{20}$. Romanii nu au avut o denumire pentru familia pe care o cunoaștem astăzi, întrucât nu au avut o astfel de realitate socială. Termenul familias $^{21}$ sublinia prevalența grupului asupra individului ${ }^{22}$. În această accepțiune, pater familias nu era un tată de familiei, ci un „stăpân” al unui grup de persoane, era persoana sui iuris, cap al unei case ca $^{23}$.

Sub puterea lui pater familias se regăseau două categorii de persoane: unele ce intrau în această categorie datorită naturii, altele datorită legii. Natural, pater familias (de sex masculin) exercita puterea asupra copiilor acestuia, de ambele sexe, asupra descendenților copiilor de sex masculin ${ }^{24}$ și a descendenților lor de sex feminin, anterior căsătoriei lor cum manu. Prin dispozițiile legislative, el exercita puterea asupra: celor ce intrau în familie prin adopție sau abrogațiune ${ }^{25}$, membrilor altor familii ce fuseseră achiziționați de pater familias cu titlu de forță de muncă și care se aflau, în aceste limite, sub puterea sa ${ }^{26}$, asupra soției sale și soțiilor fiilor săi căsătorite cum manu și asupra sclavilor săi. Denumită, după cum se pare la origini, manus ${ }^{27}$, puterea lui pater familias se va divide în patria postestas (asupra copiilor) manus (asupra soției) și dominica potestas asupra sclavilor. Titulatura de pater familias putea fi dobândită chiar de nou-născuți ${ }^{28}$, însă abia după ce aceștia dobândeau descendenți legitimi, dobândeau și patria potestas ${ }^{29}$.

Având în vedere că doar unui pater familias îi era recunoscut un drept de proprietate deplin, averea întregii familiijo era periclitată atunci când acesta ar fi fost predispus unei exploatărij ${ }^{31}$. lată spațiul de intervenție al tutelei și curatelei romane la începuturile instituțiilor! Cei ce se aflau sub puterea lui pater familias, erau sub protecția și îngrijirea acestuia, fără a necesita o tutelă sau o curatelă ${ }^{32}$. Așadar, impuberii sui iuris și femeile sui iuris, vor intra sub tutela ce intervenea în cazurile de neputință așa-zise naturale, a unei slăbiciuni datorată fie sexului (percepție existentă în cazul femeilor), fie vârstei, precum în cel al impuberilor. Puberii ${ }^{33}$, nebunii și prodigii sui iuris precum și femeile gravide, aflați fiind într-o ipostază de neputință excepțională, se vor regăsi plasați sub una dintre formele ${ }^{34}$ curatelei $^{35}$. 


\section{b) Tutela, curatela și interdicția în dreptul roman la nivel lingvistic}

Tutela, din punct de vedere etimologic se explică prin apelul la un derivat al verbului tueor-ěris ${ }^{36}$ (a vedea): *tūt-ēla cu sensul de „apărare”; tūtō cu sensul de a proteja, a păzi, tūtor cu sensul de protector. ${ }^{37}$ Cuvântul latin cūra-ae transmitea cel mai probabil intenția din spatele măsurii, sensul său comun fiind cel de îngrijire ${ }^{38}$. Termenul se opunea neglijenței transpuse în cuvântul latin incūria. În spațiul administrativ și juridic, dominant a fost însă sensul de direcție, conduită, administrare ${ }^{39}$.

Nebunii au fost clasificați în două categorii distincte: mente captus (cei slabi de minte) și furiosus ${ }^{40}$. Cei din urmă erau acei bolnavi mintali care manifestau semne evidente ale afecțiunii lor, dar nu neapărat de o manieră continuă ${ }^{41}$.

Aceștia au fost considerați ca fiind sub o pedeapsă divină ${ }^{42}$, se considera că natura (sau de zeitățile infernului- furiile ${ }^{43}$; spiritele rele ale morților - larvœle ${ }^{44}$ etc) le controlau viața și îi făceau să fie incapabili să își gestioneze patrimoniul. Aceștia erau considerați incapabili de a înțelege și a acționa, lipsindu-le capacitatea de a înțelege (intellectus), înțelepciunea (mentis, sensus, iudicium) și discernământul (exactum consilium $)^{45}$. Aceștia nu puteau, așadar, să încheie niciun act juridic ${ }^{46}$, fiind asimilați unui copil sau unei persoane adormite ${ }^{47}$.

Toți intrau, de drept, anterior instituirii curatelei dative, sub curatela ${ }^{48}$ agnaților $^{49}$, conform legii celor XII Table (Tabla 5. 7a) ${ }^{50}$.

Interdicția, deși își are originea în reglementarea romană, nu a fost dedicată nici nebunilor, dar nici celor slabi de minte. Ea era rezervată prodigilor, având un caracter punitiv ${ }^{51}$ și de salvgardare a însăși grupării de persoane ce constituiau familia romană. Termenul „,interzicere”, lat. Interdicō,-is,-xī,-ctum,-ere, ce se va regăsi în denumirile măsurilor medievale și moderne de protecție ale persoanelor nebune, prezintă o etimologie proprie sferei juridice. Folosit cu sensul de „pronunțare (din dīcere cf. iūs dīcere, iŭdex) a formulei ce punea capăt unui litigiu între (inter) părți”; de „pronunțarea unei hotărâri”, ${ }^{52}$ cuvântul a purtat mereu caracterul prohibitiv transmis din relația dintre inter ${ }^{53}$ și dīcere. Alăturat interdicției, cuvântul „prodig” are și el o denotație interesantă ${ }^{54}$. Derivat din termenul ago, ${ }^{55}$ latinescul prōdigō se formează prin prefixarea acestuia cu prefixul pro (pro-ago). Aci forma derivată a grecescului ä $\gamma \omega(\mathrm{ago})^{56}-\pi \rho o-$ $\not \alpha \gamma \omega$ (pro-ago $)^{57}$ - ne este furnizată ca echivalentă cu cea a latinescului omofon, ${ }^{58}$ atunci când prōdigō, ca verb, va purta sensul de „a face să se deplaseze înaintea sa, a fi împins înaintea sa” (fr. pousser devant soi). Latina va dezvolta de aici înțelesurile de „a arunca înaintea sa” (fr. jeter devant soi), ${ }^{59}$ apoi într-un făgaș pozitiv, de „a se dispensa de”, de „a uza de”, „a consuma”, și într-unul negativ, care va face carieră în limbajul juridic: de „a disipa”, „a risipi”. ${ }^{60}$ Ca adjectiv, forma prōdigus, atunci când se va referi la persoane va purta înțelesul de „cel ce este extravagant", de "risipitor" (atât a resurselor materiale cât și morale); iar când va fi atașat unui comportament, va face ca acesta să fie, „necontrolat", „licențios”. ${ }^{61}$

Importanța distincției dintre furiosus și mente captus apare doar în dreptul lui lustinian, și o vom vedea aplicată în cazul căsătoriei copiilor ${ }^{62}$. În ceea ce privește curatela, atât pentru nebuni cât și pentru prodigi, avem suficiente indicii pentru a o identifica ca o măsură existentă în perioada vechiului drept roman. Cert este că persoanele sui iuris ce vor face obiectul unei curatele, vor trece sub puterea agnaților celor mai apropiați în grad, iar în lipsa acestora, în puterea gentililor care vor exercita respectiva putere de o manieră colectivă asupra acestora. 
În epoca veche și preclasică a dreptului roman aflăm că persoana centrală în cadrul grupului familial, identificată prin denumirea de pater familias, exercita puteri depline asupra membrilor grupului și asupra patrimoniului familiei ${ }^{63}$. El putea, însă, să confere, prin testament, tutela asupra impuberilor și asupra femeilor de sub puterea sa, după decesul său. Odată cu legea celor XII table ${ }^{64}$, acea persoană putea fi alta decât propriul său erede ${ }^{65}$. În lipsa unei dispoziții testamentare, tutela legitimă asupra membrilor familiei, impuberi sau de sex feminin, trecea agnatului sui iuris cel mai aproape în grad de rudenie cu persoana în cauză66. Întinderea acestei puteri, exercitate de tutore ori de curator asupra persoanelor imbuperilor sui iuris, femeilor, nebunilor și prodigilor sui iuris este discutabilă. Ce apare cu reverberație în lucrările romaniștilor este că ea urmărea în principal protejarea patrimoniului familial asupra cărora, cei ce o exercitau aveau o vocație succesorală propriu-zisă. Interesul urmărit era așadar, al grupării familiale ori a titularilor puterilor exercitate. ${ }^{67}$

În epoca preclasică, odată cu relaxarea legăturilor familiale, în urma schimbărilor socio-economice din cadrul societății romane de după războaiele pubice ${ }^{68}$ și o dată cu instituirea tutelei dative, prin lex Atilia, de către un magistrat ${ }^{69}$, se va schimba și optica măsurii. Tutela și curatela vor deveni măsuri care vor urmări interesele celor plasați sub acestea ${ }^{70}$. Curentul de accentuare a acestei protecții va continua în etapele următoare, regăsindu-se și în epoca lui lustinian. Tot în această etapă, odată cu Servius Sulpicius Rufus, la finele perioadei preclasice, vom primi și o definiție a tutelei, element ce stă mărturie, prin conținutul său, schimbării ce avea loc asupra instituției:

„Tutela este, după cum o definește Servius (Sulpicius), puterea dată și îngăduită de dreptul civil asupra unei persoane libere în vederea ocrotirii aceluia care, din pricina vârstei, nu se poate apăra singur."171

În epoca clasică, apar primele semne clare de îmbinare dintre situația prodigilor și cea a nebunilor ${ }^{72}$. Mărturie găsim într-o soluție a lui Antonius Pius, text căruia, deși i se poate reproșa că este dat într-un caz special, a fost preluat apoi în Digeste cu literă de lege, arătând că, până la lustinian și după acesta, cu toții au crezut că opinia lui Antonius Pius a fost justă.

„Împăratul Antoniu Pius a răspuns favorabil unei cereri atunci când o mamă a solicitat să-i fie numiți curatori fillor săi risipitor prin aceste cuvinte: Nu este prima oară când vedem oameni care, prin cuvintele lor, par a fi în toate mințile, dar își risipesc bunurile în așa fel încât ar cădea în sărăcie lucie dacă nu le-am veni în ajutor. Vor avea nevoie să primească pe cineva care să îl asiste cu sfatul să; întrucât este just ca să venim în sprijinul celor care, atunci când vine vorba de bunuri, se comportă ca niște nebuni." ${ }^{\prime 73}$

Tot acum aflăm de la Ulpian că părintele nebun păstra patria potestas asupra copiilor născuți dintr-o căsătorie încheiată valabil, având în vedere că aceasta nu înceta ca urmare a nebuniei sale ${ }^{74}$. Gaius arăta, totodată, că un curator nu putea face donații din bunurile nebunului, decât dacă prezentau un folos neîndoielnic pentru acesta, după cercetarea unui magistrat. ${ }^{75}$ Tot în aceeași linie de gândire, conferirea unui bun al nebunului religiei sau eliberarea unui sclav, erau văzute în afara administrării la care era chemat curatorulul ${ }^{76}$. Cert este că donațiile din bunurile celui protejat nu erau permise ${ }^{77}$, decât excepțional, curatorului, în timp ce, nebunului, în nicio circumstanță. ${ }^{78}$ 
În epoca imperială, lustinian va stabili, prin novela 115 o obligație familială de întrajutorare a celui nebun. În acest context, lustinian va stabili că succesibilii nebunului care nu îi vor acorda ajutor vor fi considerați demni de exheredare și de alte pedepse civile, iar cel care, după ce i-a somat pe descendenții nebunului, l-a îngrijit pe acela și l-a primit în casa sa, va deveni noul său succesor legitim, chiar și atunci când testatorul a testat în favoarea copiilor săi. ${ }^{79} \mathrm{Ca}$ o ultimă precizare, importantă în contextul analizei, curatela nebunilor era, până în vremea lui lustinian ${ }^{80}$, intermitentă. Ea începea și înceta odată cu pierderea și redobândirea rațiunii, iar, în intervalele lucide, persoana putea încheia ea însăși actele pe care le considera necesare: se putea căsători, putea testa, putea consimți la căsătoria copiilor săi etc. Capabil, în intervalele lucide, incapabil în cele de nebunie, iată situația capului de familie în dreptul roman.

\section{Concluzii cu privire la măsurile de ocrotire ale tutelei și curatelei romane}

Născute și organizate de o manieră unilaterală, precum toate puterile conferite de dreptul roman sub formă de prerogative pure și simple, recunoscute fără contrapardidă, tutorelui sau curatorului, în interes propriu sau în interesul grupării agnatice ${ }^{81}$, pentru prezervarea patrimoniului familial ${ }^{82}$, tutela și curatela romană au devenit, începând cu epoca clasică, sarcini impuse acestora pentru protecția incapabilului ${ }^{83}$, iar formele de tutelă, ce nu s-au putut acomoda acestei noi schimbări de optică, au dispărut ${ }^{84}$. Dincolo de acest aspect, ce este esențial de reținut este faptul că măsurile ocroteau doar o categorie limitată de persoane, iar această categorie se distanța de celelalte prin aceea că avea și posibilitatea de a dispune de bunurile grupării familiale.

Nebunii își păstrau legăturile de putere părintească asupra descendenților lor, întrucât nebunia nu punea capăt căsătoriei romane; putând constitui cel mul un motiv de repudiere, în formele ei cele mai grave ${ }^{85}$. Ei nu puteau face donații, însă, decât prin intermediul curatorului și doar dacă actul prezenta un vădit avantaj pentru aceștia. Cu toate acestea, problemele administrării bunurilor, nu erau singurele ce se puteau ivi în viața unui cetățean roman. Și căsătoria copiilor unui pater familias ${ }^{86}$ ridica problemele ei, întrucât necesita, încă din perioada primară, consimțământul acestuia și, ulterior, impunea constituirea unei dote ori a unei donații antenupțiale.

Înainte de a vedea care au fost soluțiile dreptului roman în cazul căsătoriei copiilor unei persoane aflate sub curatelă, să vedem de unde a izvorât necesitatea consimțământului acestuia și, mai apoi, care a fost evoluția dotei și a donațiilor propter-nupțiale în acest sistem de drept.

\section{(ii.) Consimțământul capului de familie, o componentă a patria potestas}

Cei ce nu erau sui iuris, erau alieni iuris, adică erau subiecți ce se subordonau lui pater familias, fiind fie alieni potestas, fie alieni manus, fie alieni mancipium. ${ }^{87}$ 
În sens restrâns, patria potestas reprezenta puterea unui pater familias, cap al unui grup familial, asupra acelor persoane ce erau legate de el prin descendența agnatică, anume asupra filii familias ${ }^{88}$.

Patria potestas a cunoscut multiple explicații din partea romaniștilor. Aceasta a fost înțeleasă fie ca o extensie a ideii de proprietate ${ }^{89}$, fie a unei idei de suveranitate ${ }^{90}$, de autoritate necesarăa ${ }^{91}$, fie a unei prerogative reieșite dintr-o imaginare a familiei micro-statale, unde capul familiei îndeplinea atât funcții publice, cât și private și religioase (era deopotrivă judecător, preot și stăpân). ${ }^{92}$ Fie, în cele din urmă, ca o putere în interesul tatălui, într-un context în care interesul tatălui era însuși interesul familiei; putere creată așadar în interesul grupului și independentă (în perioada primară) de orice configurație politică statală. ${ }^{93}$

Sub puterea părintească, anume patria potestas, se aflau inițial doar copiii dintr-o căsătorie iustis nuptiis ${ }^{94}$, însă dreptul roman va asimila treptat acestora și alte categorii de descendenți. ${ }^{95}$

Patria potestas conferea lui pater familias și consensus patris prerogativa de a consimți la căsătoria „copiilor săi” ${ }^{\prime \prime 6}$. Prin căsătoria fiului, se creau noi descendenți ${ }^{7}$ în sânul aceleiași familii reunite sub autoritatea lui pater familias, fapt ce lărgea sfera descendenților atât pentru capul familiei cât și pentru fii săi, atunci când se căsătorea un nepot de-al lui pater familias. În acest context, se solicita consimțământul amândurora: atât al lui pater familias cât și a tatălui mirelui ${ }^{98}$. Prin exprimarea consimțământului capul familiei nu doar selecta pe cei care intrau în familie $^{99}$, și se îngrijea de cei ce vor intra în aceasta ci, exercita o condiție anterioară căsătoriei, în lipsa căreia, aceasta nu își producea efecte juridice ${ }^{100}$. Cert este că acest consimțământ suplimentar intervenea doar pentru cei ce erau alieni iuris ${ }^{101}$.

Pentru lustinian, consimțământul apărea ca regulă conformă naturii și dreptului civil: „(...) et civilis et naturalis ratio suadet, in tantum ut iussus parentis pracædere debeat."102 lată textul din instituțiile sale:

„Cetățenii romani încheie o căsătorie legiuită dacă se căsătoresc în conformitate cu dispozițiile legii: bărbații să fie puberi, iar femeile nubile, indiferent dacă aceștia au calitatea de șefi de familie sau de fii de familie, cu condiția ca fii de familie să aibă și consimțământul părinților (parentum ${ }^{103}$ ) în a căror putere sunt. Și dreptul civil și cel natural dispun că așa trebuie să se procedeze, cu condiția însă ca încuviințarea părintelui să fie dată anterior (căsătoriei). [... ["104

În dreptul roman primar și în perioada clasică, consimțământul capului de familie era obligatoriu pentru valabilitatea căsătoriei. ${ }^{105}$ În acest sens s-a exprimat și un rescript al împăraților Dioclețian și Maximian spre sfârșitul secolului III î.Hr. ${ }^{106}$

„Autoritatea legii nu permite căsătoria (unei fete) cu un fiu de familie în lipsa (consimțământului) său. Nimic nu vă împiedică, așa cum cereți, să vă uniți legitim cu femeia pe care v-o doriți, dacă observați preceptele legii, cu condiția ca părintele (patris) vostru să consimtă." (t.n.d.j.)

Un alt text arăta cine trebuia să consimtă la căsătorie. În Dig. 23.2.16.1., ni se spune că:

„Fiul trebuie să consimtă la căsătoria băiatului său, dar dacă se va căsători o fiică, consimțământul bunicului este suficient."107 
Treptat, odată cu evoluția dreptului, ideilor, a moravurilor și apariția procedurii extra ordinem, ce a permis noi mijloace de coerciție a taților rău-voitori ${ }^{108}$, prerogativele conferite de patria potestas își vor pierde din vigoare ${ }^{109}$. Alături de ele, și consentis patris își va pierde caracterul absolut. MATRINGE arată că această erodare, bine-cunoscută de romaniști, a lui patria potestas, se va proiecta, cu preponderență, în perioada Imperiului și în Occident, asupra consimțământul lui pater familias la căsătoria fiilor și fiicelor de familie. ${ }^{110}$

Motivul evanescenței acestei forme a puterii părintești? Imposibilitatea amenajării unei veritabile organizări patrimoniale în contextul unei subordonări stricte a căsătoriei, consimțământului capului de familie. ${ }^{111}$

Un text din Digeste ${ }^{112}$ ne arată că, odată cu Lex Iulia ${ }^{113}$, împiedicarea cu rea-credință (termenul latin este iniuria) ${ }^{114}$ a căsătoriei sau refuzul constituirii dotei, putea fi adus la cunoștința unui magistrat care îl putea obliga pe cel indolent (aici verbul latin cōgor) să își căsătorească copilul sau să îi constituie o dotă. Măsura a fost completată; se pare; de împărații Septimiu Sever și Caracalla ${ }^{115}$, care au dat-o în competența proconsulilor și guvernatorilor de provincii.

Se aplica acest text atât fetelor cât și băieților? Autorii care s-au preocupat de acest aspect ${ }^{116}$ au căzut de acord că la început a avut ca destinatari doar fiicele și că forma finală a textului din Digeste s-ar datora exclusiv compilatorilor, ea devenind certă doar în vremea lui lustinian.

Măsurile luate de Augustus, prin lex lulia de maritandis ordinibus (18 î.Hr.) și prin Lex Papia Poppea (9 d.Hr.), vor interveni atunci când catalizatorii tradiționali ai echilibrului familial, moravurile și intervenția cenzorului, nu mai erau suficiente pentru a contrabalansa excesele capilor de familie. Totodată ele au echilibrat importanța consimțământului soților ce erau sui iuris cu cea a celor ce se aflau alieni iuris ${ }^{117}$. Deși sunt considerate drept surse primare ale intervenției magistratului, în cazul consensus patris și ale interdicției căsătoriilor forțate, măsurile au avut însă o importanță istorică juridică și socială foarte limitată. ${ }^{118}$

În perioada clasică și în epoca lui lustinian, însă, consimțământul lui pater familias putea fi exprimat și tacit. ${ }^{119}$ Consimțământul tatălui captiv, absent sau nebun (asimilat celor absenți ${ }^{120}$ ) va fi înlăturat de puterea publică.

Pe fondul acestei intervenții a statului, în suplinirea unui consimțământ nerațional al unui om obișnuit, trebuie privită și modificarea adusă ulterior de lustinian în materia consimțământului în cazul celor ce și-au pierdut uzul rațiunii. Patria potestas își schimbase fundamentul și forța, consimțământul la căsătorie, deși obligatoriu, nu mai era insurmontabil, astfel că puterea publică intervenea pentru înlăturarea piedicilor neavenite la căsătorie.

\section{(iii.) Dota - de la obicei la obligație}

Ne vom ocupa în cele ce urmează, pe scurt, de dotă ${ }^{121}$ și de donația-contrapusă acesteia pe care o regăsim deja în dreptul roman post-clasic. Vom încerca să aflăm ce este dota și ce erau donațiile propter-nupțiale, cât erau de practicate în dreptul roman, pentru a înțelege textul pe care îl anticipăm deja, din materia donațiilor din bunurile unei persoane nebune cu ocazia căsătoriei unui copil al acestuia. 
Dota $^{122}$, înțeleasă primar ca o donație făcută soțului, constând în bunuri ce femeia aducea cu sine pentru susținerea sarcinilor căsniciei ${ }^{123}$, este intim legată de căsătoria romană. Această legătură ține de rolul său accesoriu ${ }^{124}$ și necesar căsătoriei ${ }^{125}$, întrucât dota nu condiționa, per se, încheierea căsătoriei. ${ }^{126}$

Dacă femeia era, la momentul căsătoriei, sui iuris, așadar nu se afla sub puterea nimănui, aceasta suferea, prin căsătorie, un capitis deminutio minima, și intra în manus-ul soțului dacă acesta era sui iuris, deci pater familias, sau, dacă acesta se afla sub puterea unui pater familias, sub manus-ul acestuia din urmă. Odată cu acest capitis deminutio minima, bunurile femeii treceau în mâinile lui pater familias și se confundau cu celelalte bunuri ale acestuia. ${ }^{127}$

Fiica de familie, anume femeia care era alieni iuris, nu avea bunurile ei. Aceasta avea însă vocația de a moșteni, alături de ceilalți descendenți, bunurile lui pater familias. Prin căsătoria cum manu însă, ea ieșea de sub puterea capului de familie și pierdea prin aceasta și posibilitatea de a veni la succesiunea acestuia. ${ }^{128}$ În acest context, pentru a acoperi acest prejudiciu, pater familias constituia pentru fiică o dotă, constând într-o sumă de bani ce putea fi privită ca reprezentând, într-o oarecare măsură, partea sa succesorală. ${ }^{129}$

Dota a existat în toate perioadele dreptului roman, chiar și în perioada primară care nu cunoștea decât proprietatea colectivă. ${ }^{130}$. În dramaturgia romană, Titius Maccius Plautus, în secolul II î.Hr în piesa Trinummus, adresează problema dotei ${ }^{131}$. Fiului prodig i se solicită să își căsătorească sora „fără dotă”. Însă, o asemenea căsătorie, apare pentru personajele din piesă ca umilitoare și aducând mai curând a concubinaj. ${ }^{132}$

Dota dobândește în perioada clasică, caracterul unei cutume, însă autorii moderni par să se pună de acord asupra caracterului non-obligatoriu al acesteia: obligația de a dota nu era o datorie juridică propriu-zisă ${ }^{133}$, ci una morală. Doar anumite persoane erau obligate, pe cale administrativă și excepțional, să constituie o dotă ${ }^{134}$; spre exemplu, când promiteau o asemenea dotă. Același lucru pare să fie valabil și pentru logodnă. Cu acestea, în perioada clasică, dota servea ca probă a existenței consimțământului la căsătorie și la affectio maritalis, pentru a o distinge de un simplu concubinaj. ${ }^{135}$.

Textul din Digeste ce făcea trimitere la posibilitatea suplinirii consimțământului tatălui și obligarea acestuia la constituirea unei dote (Dig. 23.2.19), citat în contextul consimțământului tatălui la căsătorie a fost dezbătut de romaniști ${ }^{136}$ și considerat interpolat. Aceștia au concluzionat că nici sub Lex Iulia, nici sub constituțiile împăraților Septimius Severus și Marcus Aurelius Antoninus (Caracalla) ${ }^{137}$, dota nu a constituit o veritabilă obligație juridică.

Într-un alt text din Digeste ${ }^{138}$, Publius luventius Celsus (sec. II d.Hr.) este citat pentru a lămuri dacă trebuia să fie restituită dota constituită de bunicul patern în favoarea nepoatei acestuia, tatălui, în cazul în care bunicul murise, iar apoi murise și nepoata.

„Echitatea face, ca ceea ce tatăl meu, în considerarea calităților mele, în numele fiicei mele a donat, să fie considerat donat ca de mine însumi; mai mult, datoria unui bunic față de propria nepoată depinde de afecțiunea bunicului față de propriul fiu (ex officio patris erga fillium pendet) și întrucât un tată trebuie să îi constituie o dotă fiicei sale, pentru aceleași motive, un bunic, nepoatei sale trebuie să îi constituie una (et quia pater filiae ideo avus propter filium nepti dotem dare debet.). (t.n.d.j.)"139 
Și acest text este contestat ca reprezentând o obligație morală în vremea lui Celsus în timp ce ultima parte, păstrată de noi în latină, este considerat a reprezenta un adaos al lui Iustinian. ${ }^{140}$

Un alt text, de data aceasta aparținând lui Ulpian, arată că:

„Dacă un libertus (om eliberat) constituia o dotă fiicei sale, ceea ce a dat ca dotă, nu este în frauda patronului, întrucât acest act de constituire de dotă este un act de pietate paternă ce nu poate fi blamată" (t.n.d.j.) $)^{141}$

Din confruntarea acestui text cu cel din Basilicale, în care „pietatea paternă” este eliminată, GUGLIELLMO ajunge la concluzia că dotalitatea nu era obligatorie în epoca lui ULPIAN, care, pentru a marca datoria morală a tatălui și a salva actul în detrimentul obligației dintre libertus și patronul său, a făcut apel la ideea de pietate. Odată cu obligativitatea sa, sub lustinian, s-a simțit nevoia înlăturării acestei trimiteri din textele Basilicalelor. ${ }^{142}$

O novelă a împăratului Maiorianus (al Imperiului Roman de Apus) datată octombrie 458 d.Hr. stabilea că uniunea dintre un bărbat și o femeie, fără dotă, atrăgea infamiai ${ }^{143}$ și totodată că nu putea fi considerată drept căsătorie ${ }^{144}$. Novela a fost însă abrogată în 463 d.Hr. printr-o Novelă a Împăratului Sever ${ }^{145}$. MATRINGE considera, însă, că dispozițiile lui Maiorianus erau „străine de o obligație familială de a dota copiii sau rudele ce se căsătoreau, precum și de idea de a constitui un contra-aport celui adus de soție sau de părinții acesteia."146

$\mathrm{Cu}$ toate acestea, constituirea dotei a fost, atât pentru perioada romană veche preclasică, cât și pentru perioada clasică, în ciuda expresiei sale juridice limitate, o realitate socială importantă și de necontestat. ${ }^{147}$ Această cutumă de a constitui dota la căsătoria fiicelor, cât și a unei donații antenupțiale, la căsătoria fiilor, apare în această perioadă adânc înrădăcinată în societatea romană.

Obligația de a dota, atribuită în general rudelor apropiate, se va generaliza abia în dreptul bizantin. ${ }^{148}$ Obligația de constituire a dotei devine certă în dreptul lui lustinian. ${ }^{149}$ Scopul obligativității constituirii dotei va deveni acela de a dispersa orice dubiu asupra naturii legăturii conjugale și asupra legitimității copiilor născuți din această uniune. Importante în acest sens vor fi constituțiile împăraților Zenon, din 477 d. $\mathrm{Hr}^{150}$, Anastasie, din anul 517 d. $\mathrm{Hr}^{151}$, și lustinian, din $529^{152}$ și 530 d. $\mathrm{Hr}^{153}$.

Între obligativitatea dotei, ca obligație părintească, și necesitatea sa, ca precondiție la încheierea unei căsătorii, este o mare diferență.

În novela 74.4.1 lustinian va obliga pe cei care erau însărcinați cu înalte dregătorii, să contracteze căsătorie doar însoțită de dotă. Aceasta va rămâne, după dispariția celorlalte ipoteze, singurul caz în care dota va condiționa căsătoria romană. ${ }^{154}$

Revenind la obligații în sarcina părinților, în anul 500 d.Hr. lustinian impunea părinților eretici să constituie dote și donații antenupțiale pentru copiii lor ortodocși155. Într-un alt text din $\operatorname{Cod}^{156}$, lustinian va arăta că

"Neque enim leges incognitae sunt, quibus cautum est omnimodo paternum esse officium dotes vel ante nuptias donationes pro sua dare progenie." 
„Aceste legi, ce declară că este de datoria tatălui să constituie o dotă sau o donație ante-nupțială pentru descendenții săi, sunt bine cunoscute." (t.n.d.j.)

Și alte texte din perioada lui lustinian, sugerează aceeași realitate juridică și socială ${ }^{157}$.

S-a ajuns ca o altă specie de donație să fie constituită cu ocazia căsătoriei, ce va purta numele de ante nuptias donationem.

Acest tip de donație apare ca una specifică soțului, ce se realiza, fie de către soț, fie de către capul său de familie sau de un altul în numele său, cu prilejul căsătoriei, sau în imediata ei vecinătate, fiind subordonată încheierii acesteia. Scopul său a fost acela de a susține și a favoriza familia în formare, și în caz de deces al unuia dintre soți, să permită soțului supraviețuitor să se întrețină pe sine și pe eventualii săi copii ${ }^{158}$. Prima mențiune apare în 386 d. Hr. ${ }^{159}$

Valentinian al III-lea va dota și donațiile nupțiale vor trebui să aibă aceeași valoare ${ }^{160}$, iar împărații Leo și Maiorianus vor stabili că fata ce se va căsători nu va constitui o dotă mai mică decât donația antenupțială pretinsă ${ }^{161}$.

lustinian va permite ca donațiile antenupțiale să fie efectuate și după căsătorie, de aceea le va schimba denumirea în propter nuptias ${ }^{162}$. Tot în vremea sa, donațiile propter nuptias devin un contra-echivalent dotei, de aceea împăratul va stabili că ceea ce este valabil pentru dotă, va fi valabil și pentru donațiile propter nuptias ${ }^{163}$. Tatăl va fi obligat, așadar, să constituie atât o dotă pentru fiice, cât și o donație propter nuptias pentru fiul său ${ }^{164}$.

\section{(iv.) Consimțământul la căsătorie și constituirea dotei pentru descendenții părintelui nebun}

Nu de puține ori s-a ajuns la situația în care un pater familias slab de minte (mente capti), ori aflat într-un moment de nebunie (furiosus), să fi avut copiii care să fi trebuit să se căsătorească. În acest context, în care consimțământul lui pater familias nu putea fi dat, cum s-ar fi putut căsători copiii acestuia? Dacă dota devine o obligație pur juridică în vremea lui lustinian, cum se putea ea constitui pentru copiii unui furiosus?

Mai multe texte vor adresa problema căsătoriei copiilor persoanelor nebune $e^{165}$.

În ordine cronologică, s-a admis căsătoria fetelor și băieților fără consimțământul tatălui slab de minte (mente capti), printr-o constituție a împăratului Marcus ${ }^{166}$.

„Dacă copiii ce se află sub puterea unui furiosi parentis, s-ar putea căsători, este o chestiune controversată la anticii jurisconsulți și aproape toți anticii fondatori ai dreptului au admis că fiica unui nebun se poate mărita. Ei au crezut, prin urmare, că este suficient ca tatăl să nu se opună. Din contră, au existat dubii în ceea ce îi privește pe fiii de familie. și Ulpian, pe bună dreptate, a invocat o constituție a împăratului Marcus care nu vorbește de nebun (furioso), ci de o manieră generală, de fii unui dement (fillis menti capti), care fie băieți, fie fete, puteau să se căsătorească, pretinzând că ar putea face aceasta, chiar în lipsa autorizării prințului (principem). Și o nouă îndoială a apărut (pentru lustinian ${ }^{167}$ ), dacă ceea ce constituția spune despre dement (demente) se poate aplica și nebunului (furiosis). (t.n.d.j.)"168 
Din acest text reiese că, pentru fiicele unui furiosus, jurisconsulții clasici au admis încheierea căsătoriei fără consimțământul patern ${ }^{169}$. Și interpretarea următorului pasaj din Instituțiile lui lustinian sugerează aceasta :

„este conform regulii naturii cât și dreptului civil ca acesta, (consimțământul celui sub puterea căruia se află) să fie obținut(t.n.j.d.)"170

„De unde și (următoarea) problemă : poate oare fiica unui nebun să se căsătorească sau fiul unui nebun să se însoare? Deoarece, cu privire la situația fiului opiniile erau împărțite, am dat o constituție prin care am îngăduit ca fiul unui nebun să poată - asemenea fiicei - să încheie o căsătorie potrivit procedurii prescrise în această constituție și fără încuviințarea tatălui." ${ }^{\prime 71}$

NOAILlES explică sensul termenilor de furiosus și mente captus. Primii erau cei ce reveneau la momente de luciditate, în timp ce ultimii, deși poate aveau o afecțiune mai puțin gravă, aveau o stare de sănătate iremediabil afectată, fără a mai reveni la stări lucide ${ }^{172}$. Autorul considera că, pentru autorii clasici, intervalele lucide ar fi permis intervenția părintelui furiosus, motiv pentru care fiii trebuiau să aștepte această întoarcere la luciditate, în timp ce, pentru părintele mente capti, întrucât această revenire nu mai era previzibilă, s-a admis căsătoria copiilor indiferent de sex. ${ }^{173}$

De ce era situația diferită în cazul fiilor? Întrucât aceștia puteau, prin căsătorie, să mărească numărul succesorilor lui pater familias sau ai tatălui lor, motiv pentru care, se pare, jurisconsulții au fost reticenți în a le acorda beneficiul căsătoriei. ${ }^{174}$

În continuare (C. 5.4.25) lustinian pune de acord toate chestiunile anterior expuse:

„Pentru a distruge orice îndoială, noi ordonăm ca ceea ce pare lipsă în constituția împăratului Marcus, să fie suplinită de dispozițiile următoare: descendenții, indiferent de sexul lor nu doar a celui slab de minte dar și a celui nebun, pot contracta o căsătorie legitimă, dota acestora cât și donațiile antenupțiale vor fi realizate de curatorul aceluia: estimarea se va face în acest Oraș regal exclusiv de praefecti urbis, în provincii de guvernator (presidum) sau ierarhul locului (locorum antistitum) ce vor ține seama, la stabilirea moderației dotei și a donațiilor antenupțiale, de reputația persoanei. La această estimare vor fi prezenți curatorul dementis vel furiosus precum și membrii cei mai importanți ai familiei, astfel încât nimic să nu reiasă din cauza aceasta, nici în Orașul regal și nici în provincii, pentru a cauza o pagubă furiosi vel mente capti iar această operațiune se va face gratuit, astfel încât nefericirea omenească, să nu fie agravată de nicio cheltuială."(t.n.d.j.)

Textul se regăsește quasi-identic și în C. 1. 4. 28. :

„Descendenții atât ai unui furiosus cât și a unui menti capti, indiferent de sexul lor, vor putea contracta o căsătorie legitimă. Dota acestora cât și donațiile antenupțiale vor fi realizate de curatorul tatălui, estimarea acestora, se va face în Orașul regal de praefecti urbis, iar în provincii de guvernatorul (presidum) sau ierarhul locului (locorum antistitum) care vor stabili măsura dotei și a donațiilor antenupțiale, conform reputației persoanei. Această estimare trebuie să se facă în prezența curatorului celui furiosus sau menti capti și a celor mai apropiate rude ale copiilor aceluia. La această estimare vor fi prezenți curatorul dementis vel furiosus precum și membrii cei mai importanți ai familiei, astfel încât nimic să nu reiasă din cauza aceasta, nici în Orașul regal și nici în provincii, pentru a cauza o pagubă furiosi vel mente capti iar această operațiune se va face gratuit, astfel încât nefericirea omenească să nu fie agravată de nicio cheltuială."(t.n.d.j.) 
În ceea ce privește donațiile, trebuie să spunem că dreptul roman nu permitea curatorului să realizeze donații din bunurile unui furiosus, decât în mod excepțional.

Acest caracter excepțional, proclamat de GAIUS, viza ipoteza în care donația aducea un mare avantaj pentru nebun și era realizată cu cunoștința magistratului ${ }^{175}$. Iustinian cunoștea aceasta când a permis constituirea dotei și a donațiilor antenupțiale în cazul căsătoriei unui copil al unui furiosus, însă în epoca sa, dotalitatea devenise obligatorie pentru ca o fiică să își poată găsi un soț ${ }^{176}$, la fel și donațiile propter-nupțiale căpătaseră caracterul unui contra echivalent necesar.

Mai mult, se stabilise deja de SABINUS și ULPIAN la începutul erei noastre, că, dacă un curator al unui nebun, al unui risipitor ori a altcuiva, constituia o dotă, aceasta păstra caracterul profecticiam fiind deci considerată ca provenind de la tatăl nebun (în cazul nostru) ${ }^{177}$.

\section{Concluzii cu privire la căsătorie și constituirea dotei și donațiilor ante-nupțiale în cazul persoanelor nebune}

Așadar, marele avantaj pe care dota și donațiile propter-nupțiale le aduceau cu sine unui furiosus, era fără doar și poate căsătoria copiilor, și, prin aceasta, continuitatea familiei.

Textul analizat, prin chiar plasarea lui, arată că nu vine doar să reglementeze suplinirea unui consimțământ. Dota devenise obligatorie prin constituțiile împăraților și aflăm că, în timpul lui lustinian, se obișnuia ca familia mirelui să ofere o donație antenupțială, de o valoarea echivalentă dotei, viitoarei soții.

În ceea ce privește destinatarii donațiilor antenupțiale și a dotei, textul latin folosește substantivul liber, liberi. Sensul său trebuie căutat în înțelegerea acordată lui în spațiul dreptului roman: într-un extras din întrebările lui Callistratus, preluat în Digeste, ne este furnizată următoarea denotație a termenului: prin liberorum se înțelegeau toți descendenții unei persoane, iar legea celor XII table îi cuprindea pe toți aceia. Pentru cazurile în care se dorea nominalizarea doar a unei anumite categorii de descendenți, legea obliga la utilizarea unor cuvinte specifice precum fii (fillii), nepoți (nepotes), strănepoți (prenepotis) ${ }^{178}$.

Cu toate acestea, nu trebuie uitat că, deși oricare descendent putea fi subiectul unor donații antenupțiale, nu toți ascendenții erau ținuți să realizeze acele daruri, ci, atunci când existau părinți în viață, aceia aveau obligația de a dota și, doar în subsidiar, obligația se transmitea bunicilor și străbunicilor.

lustinian va îndrepta lucrurile și va conferi atât fetelor, cât și fiilor, posibilitatea de a se căsători, iar consimțământul tatălui urma să fie suplinit de puterea statală. Tot cu această ocazie, se constituia de către curator și dota, și bunurile ce se ofereau cu ocazia căsătoriei. Aceste donații urmau să se impute pe partea legitimă a moștenitorilor, pentru a nu conduce la atacarea ulterioară a testamentului.

\section{(v.) Concluzie asupra problemei în dreptul roman}

Vedem așadar că, odată cu aportul lui lustinian, se închide un arc de cerc conceptual, asigurându-se o poziție de egalitate juridică acolo unde echitatea o impunea: copiii unei persoane afectate de nebunie, urmau să beneficieze de aceeași poziție ca și copiii unei 
persoane în puterea rațiunii. Astfel, regula de drept se arată și se poziționează deasupra slăbiciunii naturale a omului și asigură o carantină a legii asupra degradării naturale.

lată, așadar, climatul în care va interveni lustinian. Consimțământului capului de familie la căsătoria copiilor i-a fost erodată funcția de expresie a puterii parentale, fiind înlocuit, treptat, cu cel al interesului copiilor. În acest context, consimțământul patern putea fi omis când interesul copiilor era neîndoielnic. Astfel, pentru părintele care nu putea să îl exprime, acest consimțământ nu mai era necesar căsătoriei descendenților săi, întrucât nu mai putea deservi scopului său inițial: de a expune autoritatea capului de familie.

În ceea ce privește constituirea unei dote, aceasta devenise, din obligație morală, o obligație cu un izvor juridic, ba mai mult, și familia soțului constituia o donație, echivalentă dotei, în favoarea soției, cu ocazia căsătoriei.

lată rolul donațiilor din bunurile unei persoane fără uzul rațiunii în dreptul roman! A asigura egalitatea între viitorii soți, acolo unde donațiile cu ocazia căsătoriei deveniseră la ordinea zilei.

\section{(2) Dreptul francez}

\section{(i.) Dota în vechiul drept francez}

În regiunile de drept scris ${ }^{179}$ din Franța ${ }^{180}$, dota era înțeleasă ca survenind, natural din obligația alimentară a tatălui și a mamei față de copiii acestora. Așa cum am amintit deja, nu se mai efectuau căsătorii fără dotă. ${ }^{181}$

Constituirea dotei era considerată o obligație a tatălui fiind cunoscut și aplicabil

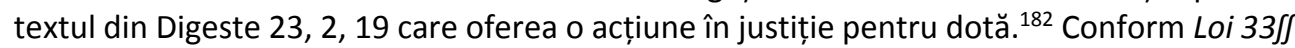
de pactis acompaniată de o notă a lui Godefroy dotare noptem ex filio avus paternus cogitur, s-a reținut că, în lipsa tatălui, bunicul are această obligație. S-a mai amintit că atât dota, cât și donațiile antenupțiale, sunt o obligație a părintelui ${ }^{183}$.

La fel ca în dreptul roman, tatăl putea refuza motivat constituirea dotei, precum în cazul în care fiica majoră dorea încheierea unei căsătorii ce ducea la o alianță defavorabilă din perspectiva tatălui. ${ }^{184}$

Mai adăugăm aici câteva chestiuni care ni se par utile demersului nostru. în această perioadă a dreptului vechi francez, tatăl era obligat să își înzestreze fiica, indiferent dacă era sub puterea sa sau era emancipată. Obligativitatea dotei se extindea și la constituirea unei noi dote, dacă prima pierise fără culpa fetei. De asemenea, obligația se extindea la bunicul patern, dacă tatăl era încă sub puterea părintească a acestuia. ${ }^{185}$ Mama nu era obligată la a dota fiica decât în cazuri excepțional prevăzute, precum în cazul în care rudele paterne ar fi sărace, iar fiica nu ar avea mijloacele necesare pentru a-și constitui singură o dotă. ${ }^{186} \mathrm{Nu}$ am putut însă identifica niciun text care să fi aplicat, în vechiul drept francez, regula din dreptul roman. Și atunci când se va scrie despre art. 511 C.civ.fr., autorii vor prefera să trimită la reglementările romane, sărind peste orice altă aplicare națională. 


\section{(ii.) Continuitatea reglementării în dreptul francez o dată cu adoptarea Codului civil francez 1804 \\ Codul civil francez de la 1804 va cunoaște o prevedere similară celei romane. Unele surse indică ${ }^{187}$ legătura dintre viitoarea reglementare franceză și textele din Codul lui lustinian. În cele ce urmează vom examina apariția normei ce permitea donațiile din bunurile celui pus sub interdicție (art. 511 C.civ.fr.) ${ }^{188}$, în procesul legislativ de adoptare al Codului Civil francez de la 1804. \\ Imboldul redactării definitive și adoptării Codului civil de la 1804, va veni în perioada Consulatului ce va constitui o etapă de stabilizare politică prin reinstituirea ordinii ${ }^{189}$, concomitent cu consolidarea treptată a puterilor primului consul, Napoleon BONAPARTE.}

\section{(iii.) Redactarea Codului civil francez de la $1804^{190}$}

Codul Civil francez de la 1804 va lua ființă după eșecul politic a patru principale proiecte de $\operatorname{cod}^{191}$ și după o dezbatere, mai mult sau mai puțin fructuoasă al celui de-al cincilea ${ }^{192}$ După ce primele trei proiecte, redactate de CAMBACÉRÈs ${ }^{193}$ vor fi respinse ${ }^{194}$, va urma un proiect prezentat de Jean-Ignace JACQUEMINOT ${ }^{195}$ și un ultim proiect, pe care îl regăsim în lucrarea lui FENET ca fiind al Commision de Gouvernement ${ }^{196}$.

Acest ultim proiect este realizat la propunerea lui Napoleon BONAPARTE ${ }^{197}$ de o comisie guvernamentală, în perioada Consulatului, formată din TRONCHET ${ }^{198}$, BIGOTPRÉAMENENU ${ }^{199}$ și PORTALIS ${ }^{200}$, avându-I ca secretar-redactor pe Jacques de MALLEVILE ${ }^{201}$.

Comisia reușește într-un termen record de doar patru luni ${ }^{202}$ să ducă la îndeplinire sarcina. Însă, Proiectul de Cod nu se va naște din neant. Membrii comisiei guvernamentale s-au distanțat de dreptul revoluționar și au dorit să afirme originalitatea operei acestora. Prin aceasta, Proiectul de Cod Civil a fost mai aproape de maximele dreptului roman și de regulile dreptului vechi ${ }^{203}$ decât de imboldul inovant al dreptului revoluționar. ${ }^{204}$ Codul ce va rezulta nu va fi însă un Cod vechi, ci va fi guvernat de imboldul revoluționar, care a permis redactarea și adoptarea sa. La nivel de conținut, va cunoaște, ca sursă primară, nu textele antice, ci textele perioadei premergătoare lui ${ }^{205}$. Aproximativ 200 de texte sunt preluate, mot à mot, din cel de-al treilea proiect al lui CAMBACÉRÈs. ${ }^{206}$ Altele, vor fi preluate și din celelalte proiecte. ${ }^{207}$

Proiectul de Cod va fi apoi transmis, spre dezbatere, către puterea judecătorească, anume Curtea de Casație și Curțile de Apel.

După primirea observațiilor, primele proiecte-lege ce vor compune Codul civil vor fi transmise, într-o procedură constituțională, camerelor decizionale.

(iv.) Apariția textului ce permitea constituirea de dotă din bunurile părintelui nebun

O dovadă în plus că cel de-al cincilea proiect de Cod Civil a avut ca sursă lucrările efectuate anterior este și norma juridică pe care o analizăm și care va fi încapsulată în viitorul art. 511 al Codului Civil Francez. 
Aceasta apare pentru întâia oară208 în ce-l de-al patrulea proiect de cod Civil, al lui Jean-Ignace JACQUEMINOT ${ }^{209}$, la art. 55 din secțiunea II De l'interdiction ${ }^{210}$ Title [II]

Textul este apoi preluat, tel que ${ }^{11}$, în proiectul comisiei guvernamentale instituite de Napoleon ${ }^{212}$. Acest ultim proiect va fi trimis pentru observații au Tribunal de cassasion și aux Tribunaux $\left.d^{\prime} A p p e\right|^{213}$, însă va fi renumerotat după discuțiile privind împărțirea materiei Codului Civil din cadrul Conseil d'État. ${ }^{214}$ Această numerotare face ca art. 52 din titlul X al capitolului II din proiectul comisiei guvernamentale, așa cum apare redat în lucrarea lui FENET $^{215}$, să ajungă art. 24 din titlul XI: De la majorité. De l'interdiction et du Conseil judiciaire ${ }^{216}$ în timpul dezbaterilor proiectului.

În fața Conseil d'État, acest text va fi avut în vedere în ședința din 11 noiembrie $1802 .^{217}$

Cu această ocazie, va interveni Jean-Jacques Régis CAMBACÉRÈs care va aduce textul în forma sa finală. Conform acestuia :

" La famille ne doit être appelée qu'à donner un avis soumis ensuite aux tribunaux. Sans cette précaution, les enfants pourraient abuser de la disposition établie par cet article. $\|^{218}$

lată forma finală a viitorului art 511, așa cum a fost adoptată în ședința din 11 noiembrie 1802 și prezentată în noua redactare a titlului din ședința din 25 noiembrie $1802^{219}$ și în forma definitivă în 12 martie $1803 .^{220}$

"Lorsqu'il sera question du mariage de l'enfant d'un interdit, la dot ou l'avancement d'hoire, et les autres conventions matrimoniales, seront réglées par un avis du conseil de famille, homologué par le tribunal sur les conclusions du commissaire du guvernement. $~^{221}$

EMMERY alături de TREILHARD și Gouvion-SAINT-CYR au prezentat proiectul titlului XI în fața Corps Legislatif în ședința acestuia din 28 venteose an XI (19 martie 1802) și au susținut proiectul în ședința din 8 germinal an XI. Așa cum am văzut, proiectul era susținut de primul orator desemnat, acesta fiind, pentru titlul XI, EMMERY.

$\mathrm{Cu}$ prilejul expunerii de motive din fața Corps Legislatif, EMMERY face cunoscute câteva gânduri aflate în spatele articolului. Să îl urmărim:

" Si'il est question de marier l'enfant d'un interdit, les conventions matrimoniales seront réglées par un conseil de famille, dont l'avis aura toujours besoin d'être homologué par le tribunal, sur les conclusions du commisaire du gouvernement. Dans l'intention de la loi, cette homologation ne doit pas être une vaine formalité ; le tribunal ; le commisaire du gouvernement sont étroitement obligés, par les devoirs de leur place, de s'assurer que les interétès de l'enfant et ceux de l'interdit ne sont pas sacrifiés à des intérètes opposés qui peuvent exister au sain même de leur famille. "1222

Proiectul de lege a fost transmis de către Corps Legislatif, Tribunat-ului printr-o comunicare oficială în 30 ventose an XI (21 martie 1803). În fața Assemblée gérnerale a Tribunatului, tribunul Bertrand de GREUILLE, va prezenta raportul comisiei de legislație în data de 5 germinal an XI (26 martie 1803). Oprindu-se asupra art. 24 din proiect, acesta va remarca : 
"Après avoir précieusement conservé les plus grands et les plus chers intérêts de l'interdit, le projet de la loi déploie toute sa sollicitude en faveur de ses enfants. C'est déjà trop pour eux du fardeau imposé à leur tendresse et à leur sensibilité ; il ne faut pas qu'ils restent victimes de l'humiliant et pénible état de leur père ; il faut leur faciliter les moyens de s'établir ; il faut donc qu'une autorité bienveillante et légale remplace autant que possible l'affection et la générosité d'un père qui ne peut plus être consulté, puisqui'il n'a plus de volonté : c'est encore le conseil de famille qui vient, dans ce cas, interposer son officieuse autorité. II règle la dot, les avantages et toutes les autres conventions matrimoniales; mais cette opération est soumise aux réquisitions du commissaire et à I'homologation du tribunal, qui s'assure, avant de l'accorder, que les sacrifices que l'on exige du père sont basés sur sa fortune, qu'ils ne sont pas exorbitants, et tels qu'ils puissent absorber les dépences nécessaires qu'entraine la ténacité de la maladie sous laquelle il gémit. $~^{223}$

Considerentele par cunoscute. În marea lor parte sunt cele ale lui lustinian, expuse în Codul său, pe care deja le-am parcurs. În ședința din 8 germinal an XI (29 martie 1803) cei trei tribuni desemnați de către Tribunat, vor susține punctul de vedere al acestei camere, în fața Corps Legislatif.

Tribunul TERRIBLE va fi desemnat să redacteze raportul din partea Tribunatului. Observațiile sale, cu privire la art. 24 se reduc la următoarele :

"Les dispositions des articles (...) n'ont pas besoin d'analyse pour justifier leur utilité : elles ne frappent paas seulement l'esprit, elles remuent le cœur et y réveillent les sentiments du respect et de la reconnaissance. (...).

Elles étendent leur prévoyance jusqu'à l'etabissement des enfants et aux moyens de le procurer.

Elles confient le soin de régler ces divers objets à la sagesse et au zèle du conseil de famille.

Le législateur semble quitter sa voix imposante pour emprunter le langage d'un père donc la tendre sollicitude pourvoit à tous les besoins de ses enfants. $\|^{224}$

Titlul XI va fi adoptat în aceeași ședință și va fi promulgat în 18 germinal an XI (8 aprilie 1803).

\section{(3) Imposibilitatea coabitării donațiilor din bunurile părintelui nebun cu dreptul actual}

Prezenta secțiune nu poate fi decât o concluzie mai amplă asupra celor deja relatate. În dreptul roman post-clasic, conferirea posibilității familiei de a acționa împreună cu curatorul în vederea constituirii de donații antenupțiale și de dotă în numele celui afectat de nebunie apare ca un act în executarea unei obligații legale de înzestrare sau de constituire de donații nupțiale pentru descendenți în contextul în care marea parte a averii familiale era încă concentrată în mâinile capului de familie. Preluarea dispoziției în C.civ.fr. 1804, dacă acceptăm că a operat o asemenea preluare, se va face într-un context de incertitudine asupra continuării regimului obligativității constituirii de dotă sub C.civ.fr. Întrucât argumentele aduse în sprijinul măsurii în contextul dezbaterii C.civ.fr. nu surprind altfel decât emoțional, legătura cu vechiul drept roman nu rămâne decât una de autoritate normativă, prin care art. 511 C.civ.fr. se autojustifica în peisajul normativ. Soluția propusă de Împăratul lustinian și-a avut utilitatea în contextul întregului sistem normativ creat de acesta în materie de căsătorie, în 
lipsa unei obligativități a constituirii de dotă ori de donații nupțiale, o dispoziție ca cea tratată, nu poate conduce decât la abuzuri și la o contrarietate de sens, raportat la orice principiu de guvernare al unei măsuri de protecție a unei persoane afectate de nebunie.

De aceea concluzionăm că posibilitatea de constituire de donații din bunurile unui părinte nebun, către descendenții săi, adoptată ca o normă necesară în dreptul roman, își pierde orice utilitate în lipsa unui regim matrimonial dotal și a unei obligativități din partea părinților de a dota sau dona copiilor acestora. Ea contravine flagrant și oricăror principii de fondare a măsuri moderne de ocrotire a persoanei majore vulnerabile.

* Asistent Universitar al Facultății de Drept a Universității Babeș-Bolyai, doctorand al Școlii doctorale de Drept a Universității Babeș-Bolyai și doctorand al Université de Nantes, Faculté de Droit et des Sciences Politiques. Email: contact : dorin.jorea@law.ubbcluj.ro.

${ }^{1}$ Referitor la donațiile ante nuptias și inovația iustiniană ce a condus la transformarea acestora în donații propter nuptias v: Carla FAYER; : La familia romana aspetti giuridici ed antiquari Parte seconda Sponsalia, matrimonio, dote, coll. "La familia romana», "L'Erma" di Bretschneider, Roma, 2005, p. 748. Pentru terminologia existentă sub codul Calimach: Ioan Scarlat CALIMACH, Codul Calimach : ediție critică, Editura Academiei Republicii Populare Romîne, București. 1958, p. 573; 703.cap. al treizeci și patru Despre darul nuntesc adecă despre contra-zestre și pentru ipovolon (văduvăritul).

${ }^{2}$ Art. 511 crée par Loi 1804-02-07 promulguée le 17 février 1804 ; Abrogé par art. 22 de la Loi n68-5 du 3 janvier 1968, JORF 4 janvier 1968 p. 114, en vigueur le $1^{\text {er }}$ novembre 1968 :

" Lorsqu'il sera question du mariage de l'enfant d'un interdit, la dot, ou l'avancement d'hoirie, et les autres conventions matrimoniales, seront réglés par un avis du conseil de famille, homologué par le tribunal, sur les conclusions du procureur impérial. "

${ }^{3}$ Codicele civil sau Codul civil din 1864, decretat la 26 noiembrie 1964, promulgat la 4 decembrie 1864 și pus în aplicare la 1 decembrie 1865. Publicat în M.Of. nr. 271 din 4 decembrie 1864 și M.Of. nr. 7 (supl.) din 12 ianuarie 1865, nr. 8 (supl.) din 13 ianuarie 1865, nr. 8(supl.) din 14 ianuarie 1865, nr. 11 (supl.) din 16 ianuarie 1865, nr. 13 (supl.) din 19 ianuarie 1865. Abrogat expres prin art. 230 lit. a) din Legea 71/2011 privind punerea în aplicare a Legii nr. 287/2009 privind Codul civil, pulicată în M.Of. nr. 409 din 10 ianuarie 2011.

${ }^{4}$ Constantin Hamangiu, Nicolae Georgean, Codul Civil adnotat cu textul art. corespunzător francez, italian și belgian și jurisprudența de la 1868-1925, Vol. I (art. 1- 643), Editura Librăriei „Universala” ALCALAY \& Co., București. 1925, pp. 547-548; Dimitrie ALEXANDRESCO, Explicaţiune teoretică şi practică a dreptului civil român în comparaţiune cu legile vechi și cu principalele legislații străine, Vol. t.III p.I, 2, Atelierele grafice Socec \& Co Societate Anonimă, Bucuresti. 1909, pp. 39, 55, 293.

${ }^{5}$ C.civ. 1864, art. 456: „Când va sosi timpul de a se căsători copilul unui interdisu, destrea și toate cele'alte convențiuni privitoare la stabilirea sau căsătoria lui, se vor regula de către consiliul de familie, după încuviințarea tribunalului cari va asculta conclusiunele procurorului."

Textul a fost abrogat expres prin art. 49 al decretului nr. 32 din 1 ianuarie 1954 pentru punerea în aplicare a Codului familiei și a decretului privitor la persoanele fizice și persoanele juridice, publicat în B.Of. nr. 9 din 31 ianuarie 1954. Decretul 32/1954 a fost abrogat prin art. 230 lit. o) din Legea 71/2011 privind punerea în aplicare a Legii nr. 287/2009 privind Codul civil, publicată în M.Of. nr. 409 din 10 ianuarie 2011. 
${ }^{6}$ Codul civil Carol al II-lea, Decretul nr. 3993 din 7 noiembrie 1939 și publicat în M.Of. p. I, nr. 259 din 8 noiembrie 1939, modificat prin Decretul-lege privind modificarea Codului civil Carol al II-lea, publicat în M.Of. partea I, nr. 200 din 30 august 1940; Republicat în M.Of. p. I, Nr. 206 din 6 septembrie 1940, abrogat expres prin art. 230 lit. h) din Legea 71/2011 pentru punerea în aplicare a Legii nr. 287/2009 privind Codul civil, publicată în M.Of. nr. 409 din 10 iunie 2011.

7 În urma decretului-lege privind modificarea Codului civil Carol al II-lea, textul art. 420 al C.civ. Carol al II-lea, a devenit art. 528 însă își va păstra conținutul.

${ }^{8}$ C.civ. Carol al II-lea, art. 528:

„Descendenții interzisului vor putea fi căpătați sau înzestrați de tutor cu autorizațiunea instanței tutelare, după ce se va lua avizul consiliului de familie, fără însă să se poată da scutire de raport."

${ }^{9}$ În indicarea textelor din Digeste, am optat să includem și textul celei mai noi traduceri a Pandectelor în limba franceză, realizată de Domminique GAURIER și apărut în 2017, tocmai datorită caracterului novator și exact al traducerii, în raport cu traducerile franceze ale lui HULOT \& BERTHELOT (1805) și Breard Neuveille (1823) (pe care le-am avut la dispoziție) și cu traducerea în engleză a lui Alan WATSON. Pentru textele din instituții, vom folosi traducerea consacrată în România a profesorilor Vladimir HANGA și Mircea Dan BoB, insistând, la nevoie, asupra anumitor nunațe de exprimare. Pentru textele Codului, vom utiliza, Traducerea în franceză a lui TIssot (1807).

${ }^{10}$ Ocrotirea putea fi fie a unui interes familial, fie a unuia individual care putea sau nu să fie cel al persoanei aflate sub tutelă sau curatelă.

11 O delimitare mai precisă dar în același timp, mai arbitrară conduce la plasarea dreptului quiritar între anii 753 Î.Hr. (anul mitic al formării Romei) la anul 367 î.Hr. al Leges Licinae Sextiae (un compromis între patricieni și plebei). V: Antonio GUARINO; : Diritto privato romano, 12e éd., Jovene, Napoli, 2001, pp. 87; 90-91.

${ }^{12}$ Corespunde Republicii romane naționale unde mecanismul republican ia locul structurii antice de funcționare corespunzând, mai precis, perioadei cuprinse între 367 î.Hr. și 27 î.Hr. În anul 27 î.Hr., lui Augustus i-a fost conferită pentru prima oară, puterea constituțională de princeps. V: idem. p. 94.

${ }^{13}$ Vladimir HANGA, Mircea Dan BOB, Curs de drept privat roman, Ediţia a 5-a revizuită şi adăugită, Universul Juridic, București. 2013, p. 25.

${ }^{14}$ Corespunde Republicii romane universale și regimului de guvernare a principatului în perioada cuprinsă din ultimii ani ai secolului 1 î.Hr. (an. 27 î.Hr). și finele secolului III d.Hr. (anul 284 d.Hr.) o dată cu finalul celei de-a treia anarhie miliater și ascensiunea la putere a lui Dioclețian. V: A. GUARINO, Diritto privato romano ... op. cit., p. 102.

${ }^{15}$ V. HANGA, BOB, M.D., Curs de drept pivat roman ... op. cit. p. 25. De observat că autorii români citați prezintă perioada istorică distinct de etapele formării dreptului roman. Astfel, perioada vechiului drept roman apare cuprinsă între perioada regalității (a dreptului quiritar și sfârșitul republicii naționale), perioada clasică corespunde republicii romane universale și principatului (romaniștii cotați consideră principatul ca fiind prima etapă a imperiului), în timp ce dreptul post-clasic apare ca fiind cel specific ultimei perioade, a imperiului (a dominatului).

${ }^{16}$ Idem.

17 Perioada cuprinsă între preluarea puterii de către Dioclețian (284-305 d.Hr. și până la lustinian I (527-565 d.Hr.). v: A. GUARINo, Diritto privato romano ... op. cit., p. 108. 
18 Inst. 1, 13, 1 : Transeamus nunc ad aliam divisionem. Nam ex his personis quae in poteste non sunt, quaedam vel in tutela sunt vel in curatione quaedam neutro iure tenentur. „Vom trece acum la o altă diviziune (a persoanelor s.n.d.j.). Dintre persoanele care nu se află sub puterea nimănui, unele sunt sub tutelă, altele sub curatelă, iar altele nu se află sub niciun astfel de drept." (t.n.d.j.) a se vedea, de asemenea: Joseph-Louis-Elzéar ORTOLAN; : Explication historique des Instituts de l'empereur Justinien avec le texte, la traduction en regard, et les explications sous chaque paragraphe; précédée de l'Histoire de la législation romaine, depuis son origine jusqu'à la législation moderne et d'une Généralisation du droit romain d'après les textes anciennement connus, ou plus récemment découverts., 8e éd., t.II, Henri Plon, imprimeur-éditeur, Paris, 1870, p. 135 ș.urm.

19 Pentru un scurt periplu asupra apariției și evoluției tutelei femeilor în dreptul roman, precum și pentru apariția curatelei sarcinii, a se vedea: Verena HALBWACHS, "Women as legal actors» în PAUL J. DU PLESSIS, ANDO CLIFFORD \& TUORI KAIUS (dir.), The Oxford handbook of Roman law and society, Oxford, Oxford University Press, 2016, pp. 448-449; Eva CANTARELLA, «Women and patriarchy in roman law» în PAUL J. DU PLESSIS, ANDO CLIFFORD \& TUORI KAIUS (dir.), The Oxford handbook of Roman law and society, Oxford, Oxford University Press, 2016, pp. 422-423, 425-428.. O dată cu reforma împăratului Augustus, mamele născute liber cu mai mult de trei copii și cele dezrobite cu patru copii, ieșeau de sub tutela agnaților. Cu toate acestea, după mărturia lui Gaius, în vremea sa, femeile se administrau singure (Inst. Gaius 1.190). v. și : V. HALBWACHS, «Women as legal actors» în DU PLESSIS, CLIFFORD \& KAIUS (dir.), The Oxford handbook of Roman law and society.. Acesta susținea că în vremea împăratului Claudius s-a abolit tutela agnaților asupra femeilor cf. Inst Gaius 1.157. O dată cu o constituție a împăratului Constantin din 321 d.Hr., se va recunoștea femeilor o capacitate egală cu cea a bărbaților, dacă doreau să o solicite, de la împlinirea vârstei de 18 ani (Cod. 2.44.2.1).

20 Pierre NoAilles; : Répétitions écrites de droit romain approfondi rédigées d'après le Cours et sous le contrôle de M. Noailles. Mariage-divorce et restitution de la dot, Les cours de droit, Paris, 19361937, p. 12; V. HANGA, BoB, M.D., Curs de drept pivat roman ... op. cit. p. 116. Puteau fi pater familias și femeile? Conform unor opinii recente, da, deși fără recunoașterea tuturor prerogativelor unui bărbat. Matthew J. PERRY, «Defining gender» în PAUL J. DU PLESSIS, ANDO CLIFFORD \& TUORI KAIUS (dir.), The Oxford handbook of Roman law and society,...op.cit. pp. 436-437; Richard P. SALLER, «Pater Familias, Mater Familias, and the Gendered Semantics of the Roman Household», Classical Philology, vol. $94 n^{\circ} 2$, 1999. Contra: V. HANGA, BOB, M.D., Curs de drept pivat roman ... op. cit. p. 117. unde se arată că numai fii, adică descendenții de sex masculin puteau deveni pater familias și că acest element era definitoriu pentru familia agnatică. A. GUARINO, Diritto privato romano ... op. cit., p. 532.unde autorul arăta că, de regulă. calitatea aparținea doar persoanelor de sex masculin întrucât ar fi operat, în dreptul roman, un bine cunoscut principiu "mulier est caput et finis familiae suae”

${ }^{21}$ Asupra sensului cuvântului familia, v: Roger HeNRION, "Des origines du mot Familia», L'antiquité classique, vol. Tome $10 \mathrm{n}^{\circ}$ fasc. 1, 1941, pp. 41-42.pentru sensul din text; Roger HENRION, «Des origines du mot Familia», L'antiquité classique, vol. Tome $11 \mathrm{n}^{\circ}$ fasc. 2, 1942, pp. 282-284.

22 Suzanne DIXON, «Family» în PAUL J. DU PLESSIS, ANDO CLIFFORD \& TUORI KAIUS (dir.), The Oxford handbook of Roman law and society, ... op. cit. p. 463.

${ }^{23}$ Dig. 50.16.192.1; Dig. 50.16.192.2 V. HANGA, BOB, M.D., Curs de drept pivat roman ... op. cit. pp. 115-116.

24 P. NOAILlES, Mariage-divorce et restitution de la dot ... op. cit., p. 16.

${ }^{25}$ A. GUARINO, Diritto privato romano ... op. cit., p. 486. Autorul analizează componenta ipotetică a familiei agnatice în perioada quiritară. Pentru abrogațiune, a se vedea: Inst. Gaius 1.97-107.

${ }^{26}$ Idem. aceștia nu dobândeau o legătură de rudenie agnatică. Despre potestas sui liberi in mancipio a se vedea: idem. pp. 537-538. 
${ }^{27}$ V. HANGA, BOB, M.D., Curs de drept pivat roman ... op. cit. pp. 115-116. Contra: P. NoAlLLES, Mariage-divorce et restitution de la dot ... op. cit., pp. 17-18. ce nu credea într-o suprapunere, la nivel originar, a acestor puteri.

28 (Dig. 50, 16, 195, 2) Justinien IER EMPEREUR de BYZANCE, DominiQue GaURIeR (trad.): Les 50 Livres du Digeste de I'Empereur Justinien comprennant - pour la première fois en français - La Palingénésie du commentaire sur l'édit du préteur d'Ulpien (d'après Otto Lenel), III - III, Éditions La Mémoire du Droit, Paris, 2017, pp. 2389-2390.

${ }^{29}$ Pentru detalii: Paul Frédéric GIRARD; ; FÉLIX SENN ET JEAN-PHILIPPE LÉvY (sous la dir. de): Manuel élémentaire de droit romain rééd. présentée par Jean-Philippe Lévy, 8e éd. revue et mise à jour par Félix Senne éd., coll. «Bibliothèque Dalloz», Dalloz, Paris, 2003, p. 149; nota 2; P. NoAlLLES, Mariage-divorce et restitution de la dot ... op. cit., p. 12.

${ }^{30}$ V. HANGA, BOB, M.D., Curs de drept pivat roman ... op. cit. p. 116.

${ }^{31}$ Tristan S. TAYLOR, «Social status, legal status and legal privilege» în PAUL J. DU PLESSIS, ANDO CLIFFORD \& TUORI KAIUS (dir.), The Oxford handbook of Roman law and society, ... op. cit., p. 350; A. GUARINo, Diritto privato romano ... op. cit., p. 493.

${ }^{32}$ Cod.lust. 5.70.7.Carla FAYER; : La familia romana aspetti giuridici ed antiquari, coll. «Problemi e ricerche di storia antica», "L'ERMA" di Bretschneider, Roma, 1994, p. 570. pentru curatela fiilor de familie nebuni.

33 Dig.. 26.3.6. Pentru curatela puberilor: idem. pp. 587-609.Și impuberii puteau fi acompaniați de o curatelă.v: idem. pp. 609-611.

${ }^{34}$ Curatela va fi denumirea care va reuni o paletă de măsuri prin care se asigură gestionarea patrimoniului, în cazuri excepționale. Acestea erau variate, de la curatela minorilor de până la 25 de ani, la curatelele numite în cadrul tutelei romane, la cea menită să evite un avort în cursul sarcinii femeii, la cea a prodigilor și nebunilor.

${ }^{35}$ Structura curatelei se adapta cazului pentru care era instituită. C. FAYER, La familia romana aspetti giuridici ed antiquari ... op. cit., p. 559.

${ }^{36} \mathrm{Cu}$ sensul vechi de a vedea, a proteja, a avea în pază Alfred ERNOUT, Antoine MEILLET; ; JACQUES ANDRÉ (sous la dir. de): Dictionnaire étymologique de la langue latine : histoire des mots, 4e éd., Klincksieck, Paris, 2001, p. 706.De aici, acțiunea de a veghea asupra, protecție, pază, gardă Félix GAFFIOT; : Dictionnaire latinfrançais, Hachette, Paris, 1934, p. 1616.

${ }^{37}$ A. ERnout, Meillet, A., Dictionnaire étymologique de la langue latine : histoire des mots ... op. cit., p. 706.

${ }^{38}$ Jean-Philippe LÉVY, André CASTALDO; : Histoire du droit civil, 2e éd., coll. «Précis Dalloz», Dalloz, Paris, 2010, p. 260.Latinescul curo-curare, ar fi avut sensul de „,a veghea”, , a observa”, ,,a avea grijă”. În limba română avem termenii derivați: „,acuratețe”, „cură”, „curatelă” etc. Conform noilor studii etnologice, latinescul curo-curare ar proveni la rândul său din proto-indo-europeană, având un contra echivalent în *kioscu sensul de "grijă", . Mihai VINEREANu, Dicționar etimologic al limbii române pe baza cercetărilor de indo-europenistică, Alcor Edimpex, București, 2008. la cuvântul "curat”.

39 F. GAFFIOT, Dictionnaire latin-français ... op. cit., p. 455; A. ERNOUT, MeILlet, A., Dictionnaire étymologique de la langue latine : histoire des mots ... op. cit., p. 159.

${ }^{40}$ C. FAYER, La familia romana aspetti giuridici ed antiquari ... op. cit., pp. 559-560. pentru sinonimia dintre termenii furiosus și demens la nivelul dispozițiilor juridice (nota. 680).

${ }^{41}$ Idem. p. 559.

${ }^{42}$ Pentru trimiterile la scrierile lui Cicero: idem.

${ }^{43}$ Despre Eumenide sau Furii și locul lor în mitologia romană, a se vedea Mathieu CHRISTOPHE; : Dictionnaire pour servir à l'intelligence des auteurs classiques grecs et latins, L. Duprat-Duverger, Paris, 1805, p. 364.

${ }^{44}$ v. Idem. p. 511. 
${ }^{45}$ C. FAYER, La familia romana aspetti giuridici ed antiquari ... op. cit., p. 560. pentru o bogată colecție de texte juridice care susțin afirmațiile, a se vedea, nota 681-684.

${ }^{46}$ Inst. Gaius 3.106.

${ }^{47}$ C. FAYER, La familia romana aspetti giuridici ed antiquari ... op. cit., p. 561.

${ }^{48}$ Ulp. Dig. 27.10.1.pr: „Lege deodecim tabulorum prodigo interdicitur bonorum suorum administratio. Quod moribus quidem ab initio introductum est. Sed soient hodiè praetores vel praesides, si talem hominem invenerint, qui neque tempus neque finem expensarum habet, sed bona sua dilacerando et dissipando profudit, curatorem ei dare exemplo furiosi. Et tandiu erunt ambo in curatione, quandiu vel furiosus sanitatem, vel ille sanos mores receperit. Quod si eveuerit, ipso jure desinunt esse in potestate curatorum.

${ }^{49}$ Vechea rudenia agnatică se baza pe legăturile de putere iar nu pe cele de sânge. V: V. HANGA, BoB, M.D., Curs de drept pivat roman ... op. cit. p. 116.

${ }^{50}$ Inst 1.15 ; Inst. Gaius 1.157; C. FAYER, La familia romana aspetti giuridici ed antiquari ... op. cit., p. 563.

${ }^{51}$ Abia în teritoriile franceze medievale va opera rocada instituțiilor și interdicția va trece, de la o măsură rezervată prodigilor, la una a nebunilor și prodigilor, urmând ca treptat, prodigii să se emancipeze și, o dată cu Codul Napoleon, interdicția să devină măsura de ocrotire doar a celor debili sau alienați mintal.

${ }^{52}$ A. ERnOUt, Meillet, A., Dictionnaire étymologique de la langue latine : histoire des mots ... op. cit., p. 320.

53 Inter reprezintă o formațiune derivată a prefixului privativ in. Ca preverb și prepoziție, inter se folosea cu sensul de „între”, „,̂n interiorul a”, la nivel spațial: „printre” și temporal: „timp de”. Cu toate acestea, atunci când intra în interiorul unor cuvinte compuse, inter aducea cu sine ideea de privațiune, de distrugere, de moarte, precum în termenii: intereō - „a muri”, „a sucomba”, „a lua

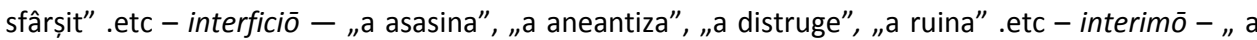
asasina”, „a suprima”, „a omorî”, ,a răvăși” .etc și interdico - „a comanda”, ,a soma”, , a opri”, ,a ordona" dar mai ales "a interzice" (al cărui sens prohibitiv este trasat, la nivel lingvistic, în protoindo-europeană, prezent în scrierile zoroastriene, unde în cuprinsul imnurilor Gatha, întâlnim în avestică termenul de antorə-mruye, „interdīcō” ce corespunde termenului latin ca, sens, formă și compunere. A se vedea: idem. pp. 311-313.la analiza termenilor in și inter.

54 Pentru etimologia și sensurile termenului ago,-is, ēgī, āctum, agere, a se vedea: idem. pp. pp.1517 ; Félix GAFFIOT, Pierre FLOBERT; : Le grand Gaffiot : dictionnaire latin-français, Nouvelle édition revue et augmentée. /e éd., Hachette., Paris, 2000, pp. 90-92; Ethan Allen ANDREWs, Wilhelm FreUnD, Charlton Thomas LEWIS, Charles SHORT; : A latin dictionary founded on Andrews' edition of Freund's Latin dictionary, Oxford University Press, Oxford, 1958, p. 89. P. G. W. GLARE; : Oxford Latin Dictionary, Clarendon press, Oxford, 1984, pp. 87-90.

${ }^{55}$ Sensurile cel mai uzuale al termenului latin ago, și care pare să fi existat în toate perioadele a fost acela de „a intenționa să”, „a face”, „,a acționa asupra”, „a tranzacționa”. Acestora li se adaugă sensurile de „a pune în mișcare”, de „a împinge înainte”, de „a conduce”, de „a ghida”, „a guverna”, de „, excita”, de „a împinge înspre un lucru”, de „a urma un curs al acțiunii”, de „a face din ceva, un obiect al unei acțiuni”. În sfera juridică a fost folosit cu sensul de „a pleda”, „a tranzacționa”, „a delibera". v. E.A. ANDrews, Freund, W., LEWIS, C.T., SHORT, C., A latin dictionary founded on Andrews' edition of Freund's Latin dictionary ... op. cit., p. 89; 1469.. Asemănător termenului åpw, omologul latin va fi avut și sensul acțiunii de „a cântări” (cf. fr. peser) a se vedea: A. ERnout, MeIllet, A., Dictionnaire étymologique de la langue latine : histoire des mots ... op. cit., p. 16.. Ago dă naștere unor termeni derivați și va fi alăturat altora. Dintre aceștia, amintim: 
Agitōōas iterativ intensiv cu sensul de a „a împinge”; „,a îndemna cu ardoare, ori cu forță”. Acroșat lumii fizice ori psihice va purta sensurile de „a nu lăsa în repaos”, „a se mișca fără încetare”. Agitātor va fi folosit în latină cu sensul de "vizitiu”, ,jocheu”, iar tardiv, de „instigator", în timp ce agitātiō a avut mai presus de toate, un sens moral de „agitație” ori „meditație, practică constantă”.

Cōgitō derivat din agō *co-agitō cu sensul de ",agitare a gândurilor", „,acțiunea de a pune în mișcare gândurile" ce va da în română "cuget" și „cugetare”. Pentru sursa latină a termenilor români, a se vedea și Dicționar etimologic al limbii române pe baza cercetărilor de indo-europenistică, Alcor Edimpex, București, 2008, p. 287..

Actus, actiō, exigō și prōdgō se pot alătura termenilor deja menționați, toți, derivați ai lui ago. Mai putem avea în vedere și sensul lui agere (,a fi activ") utilizat prin opoziție cu pati (,a fi pasiv"). Pentru detalii, a se vedea: A. ERNOUt, MeIllet, A., Dictionnaire étymologique de la langue latine : histoire des mots ... op. cit., pp. 15-17..

${ }^{56}$ Verbul ä $\gamma \omega$ poartă alături de derivatele sale, sensul original de „proces în derulare”, " " pousser ” mais très vite, "conduire»". Ramificațiile sale semantice diverse, ne sunt prezentate ca fiind diferite de cele ale omologului latin, agō. a se vedea: Pierre CHANTRAINE, Jean TAILLARDAT, Olivier MASSON, JeanLouis PERPILLOU; : Dictionnaire étymologique de la langue grecque histoire des mots achevé par Jean Taillardat, Olivier Masson et Jean-Louis Perpillou, Nouvelle éd. 2009e éd., coll. «Librairie Klincksieck Série linguistique», Klincksieck, Paris, 2009, p. 16.

${ }^{57}$ lată sensurile lui $\pi \rho 0-\alpha ̋ \gamma \omega$ [pro-ago] în limba greacă: de „a face să avanseze”, „a avansa” (în vârstă, în demnitate, în putere) „a fi împins spre” (un sentiment o acțiune), „a merge înainte” (în spațiu, în timp, în sens figurat de a depăși a trece peste ceva) dar și (sens slab) de „a crește copii“, , ,a face să avanseze afacerile”, , a conduce afacerile până la un anumit punct”, iar în forma pasivă: ,,a fi condus înainte", „a avansa, a se lăsa împins, condus înspre un sentiment, o acțiune” ș.a. a se vedea: Victor MAGNIEN, Maurice LACROIX, Raymond SALESSES; : Dictionnaire grec-français, E. Belin, Paris, 1969, pp. 1521-1522; P. Chantraine, Taillardat, J., Masson, O., Perpillou, J.-L., Dictionnaire étymologique de la langue grecque histoire des mots achevé par Jean Taillardat, Olivier Masson et Jean-Louis Perpillou ... op. cit., p. 16; Anatole BAIlly, Émile EGgeR, Louis SÉCHAN, Pierre CHANTRAINE; : Dictionnaire grecfrançais réd. avec le concours de E. Egger éd. rev. par L. Séchan,... et P. Chantraine,... avec... de nouvelles notices de mythologie et religion par L. Séchan, Hachette, Paris, 2000, p. 1624.

58 Pentru echivalența termenului grec cu cel latin, a se vedea A. ERnout, Meillet, A., Dictionnaire étymologique de la langue latine : histoire des mots ... op. cit., p. 17.

59 Idem. „Jeter” intră în câteva locuțiuni adverbiale în franceză care, în sens figurat, poartă ideea de progalitate: „,jeter l'argent par les fênetres*”; ,jeter au vent, en air*" dar și „,jeter sa tête".

${ }^{60}$ E.A. ANDREWS, FreUnd, W., LEWIS, C.T., SHORT, C., A latin dictionary founded on Andrews' edition of Freund's Latin dictionary ... op. cit., p. 1469.. Sensul de "a disipa”, „a risipi” este evident semnalat și de A. ERnout, Meillet, A., Dictionnaire étymologique de la langue latine : histoire des mots ... op. cit., p. 17.

${ }^{61}$ P.G.W. Glare, Oxford Latin Dictionary ... op. cit., p. 1472. Prodigus va purta în schimb și un sens pozitiv de „lavish”, „unstinting”. De asemenea Félix GAFFIOT semnalează și el sensul pozitiv: de „a produce în abundență”, franceza păstrând expresia "terre prodigue”. A se vedea: F.I. GAFFIOT, FLOBERT, P., Le grand Gaffiot : dictionnaire latin-français ... op. cit., p. 1261.. Mai mult, pentru o expunere a sensurilor termenului în limbajul curent în limba franceză: Anne GOTMAN; : Dilapidation et prodigalité, Nathan, Paris, 1995, p. 12.

62 C.5.4.25.

${ }^{63}$ P. NoAlLles, Mariage-divorce et restitution de la dot ... op. cit., pp. 12-13; 19. 
${ }^{64}$ Secolul al V-lea Î.Hr. v: V. HANGA, BoB, M.D., Curs de drept pivat roman ... op. cit. p. 25. între 499-451 î.Hr.

${ }^{65}$ C. FAYER, La familia romana aspetti giuridici ed antiquari ... op. cit., p. 388.

${ }^{66}$ Idem. p. 392.

${ }^{67}$ V. HANGA, BOB, M.D., Curs de drept pivat roman ... op. cit. p. 135; C. FAYER, La familia romana aspetti giuridici ed antiquari ... op. cit., pp. 392,393.

${ }^{68}$ V. HANGA, BOB, M.D., Curs de drept pivat roman ... op. cit. p. 135.

${ }^{69}$ Lex Atilia este datată anterior anului 186 î.Hr. Ea va fi extinsă în provincii prin Lex Iulia și Lex Titia. V: idem. p. 136.

${ }^{70}$ Mai puțin în cazul femeilor, unde tutela nu pare să aibă o funcție de protecție. v: C. FAYER, La familia romana aspetti giuridici ed antiquari ... op. cit., p. 395. Pentru furiosi Dig. 27.10.7. pr.

${ }^{71}$ Dig. 26.1.1.pr. Pentru traducerea în limba română: V. HANGA, BOB, M.D., Curs de drept pivat roman ... op. cit. p. 136.

72 Despre tendința de contaminare între măsurile de ocrotire din dreptul roman a se vedea: C. FAYER, La familia romana aspetti giuridici ed antiquari ... op. cit., p. 580.

${ }^{73}$ Dig. 26.5.2.

${ }^{74}$ Dig.1.6.8.; 1.6.8.1.

75 Dig. 27.10.17.

${ }^{76}$ Dig. 27.10.12. Dig. 40.9.22.

77 Dig.27.10.12; Dig.27.10.17.; Dig.40.1.13.; Dig.40.9.22 în ceea ce privește sclavii.

78 Dig.39.5.23. 1.

${ }^{79}$ C. FAYER, La familia romana aspetti giuridici ed antiquari ... op. cit., p. 573.

80 Curatela devenise în această perioadă în principal dativă, anume curatorul era desemnat de un magistrat. Dacă ea înceta în momentul redobândirii lucidității, s-a pus problema renumirii curatorului de fiecare dată când luciditatea dispărea. În acest context, lustinian va decide că se va da un curator permanent unui furiosus și, chiar dacă curatela va înceta în momentul stării de luciditate, curatorul numit își va relua funcția imediat când aceasta va dispărea. C.5.70.6.1. pr.

${ }^{81}$ Vladimir HANGA, Drept privat roman, Ed. Didactică și pedagogică, București. 1977, p. 244; Constantin Ștefan Tomulescu, Manual de drept privat roman, Tip. și litografia Ministerului invățămîntului, București. 1958, p. 253; C. FAYER, La familia romana aspetti giuridici ed antiquari ... op. cit., p. 392.

${ }^{82}$ C. FAYER, La familia romana aspetti giuridici ed antiquari ... op. cit., p. 392.

${ }^{83}$ Această evoluție se va realiza o dată cu translația grupării familiare romane dinspre o legătură de putere, agnatică, înspre o legătură de rudenie a sângelui, înspre familia cognatică. V: V. HANGA, BOB, M.D., Curs de drept pivat roman ... op. cit. p. 135.

${ }^{84}$ P.F. GIRARD, Manuel élémentaire de droit romain ... op. cit., p. 219.

${ }^{85}$ Dig. 23.3.22.7-11.

${ }^{86}$ Așa cum vom vedea, doar ascendenții de sex masculin consimțeau la căsătoria copiilor lor, nu și cei de sex feminin.

${ }^{87}$ Gaius, 1, 49-55. Pentru text și traducere în franceză: GAIUs; LÉO DOMENGET (sous la dir. de): Institutes de Gaius contenant le texte et la traduction en regard, avec le commentaire au dessous, A. Marescq Aîné, libraire-éditeur, Paris, 1866, p. 32. Pentru o altă traducere în franceză a textului: Jean Gaudemet; ; Emmanuelle Chevreau (sous la dir. de): Droit privé romain, 3e éd., Montchrestien, Paris, 2009, pp. 323-324.

${ }^{88}$ A. GUARINO, Diritto privato romano ... op. cit., pp. 533-534. 
${ }^{89}$ Guillaume MATRINGE, Individualisme et communauté dans la famille en Occident latin recherches sur les régimes matrimoniaux de l'apogée classique à la disparition de l'Empire (Thèse), Faculté de Droit de Strasbourg, Université de Strasbourg, 1959, p. 265. Pentru înțelesul conceptelor de „potestas” și „patria potestas”, a se vedea cu precădere notele 1 și 2; Guillaume MATRINGE, "La puissance paternelle et le mariage des fils et filles de famille en droit romain (Sous l'Empire et en Occident)» dans, Studi in onore di Edoardo Volterra, V - V, coll. «Pubblicazioni della Facoltà di giurisprudenza dell'Università di Roma»n ${ }^{\circ 4}$, Millano, Giuffré, 1971, p. 192; nota 6.Autorul atribuie această viziune lui Edouard Cuq însă poate fi regăsită și la Joseph-Louis-Elzéar Ortolan.

${ }^{90} \mathrm{G}$. MATRINGE, «La puissance paternelle et le mariage des fils et filles de famille en droit romain (Sous I'Empire et en Occident)", Studi in onore di Edoardo Volterra ..., op. cit., p. 192; nota 6.Viziunea este atribuită lui Pietro Bonfante. Aceasta apare însă și la Noailes care vedea familia ca un grup suveran, străîn (inițial n.n.) de intervenția Statului: v: P. NoAILlES, Mariage-divorce et restitution de la dot ... op. cit., p. 11.

${ }^{91}$ V. HANGA, BOB, M.D., Curs de drept pivat roman ... op. cit. p. 116.

${ }^{92} \mathrm{G}$. MATRINGE, "La puissance paternelle et le mariage des fils et filles de famille en droit romain (Sous I'Empire et en Occident)", Studi in onore di Edoardo Volterra ..., op. cit., pp. 192; nota 6. cu o trimitere dificilă la Girard pentru imaginea puterii capului de familie ca o extensie politică și religioasă. Autorul arăta, în același loc, că idea era împărtășită și de Pietro de Francisci; Pasajul opiniei lui Girard poate fi regăsit la: P.F. GIRARD, Manuel élémentaire de droit romain ... op. cit., pp. 13-15; V. HANGA, BOB, M.D., Curs de drept pivat roman ... op. cit. p. 116.

${ }^{93}$ Fundamentul acestei puteri părintești suverane, create în interesul familie reprezentate de capul acesteia, apare pentru NOAILLES ca provenind din cutume religioase și familiale ancestrale, acceptate de Cetatea Sacră ca atare. Intervențiile Statului în contextul puterii părintești, remarcă autorul, deși vor exista, vor fi timide și vor privi, chestiuni de detaliu survenite din evoluția dreptului roman ca atare. P. NoAIllEs, Mariage-divorce et restitution de la dot ... op. cit., p. 11. Vom reveni asupra acestei idei când vom aborda idea dotei.

${ }^{94}$ Gaius, 1, 55. Termenul desemna o căsătorie încheiată în conformitate cu ius civile de către persoane care aveau dreptul de a se căsători - conubium. A se vedea V. HANGA, BOB, M.D., Curs de drept pivat roman ... op. cit. pp. 120-127.

95 Este vorba despre copiii reieșind din căsătorii asimilate prin lege cf. Lex Aelia Sentia, sau prin constituții imperiale. De asemenea este cazul copiilor legitimați și ai celor adoptați. Pentru detalii, v: GAIUS, Institutes de Gaius contenant le texte et la traduction en regard, avec le commentaire au dessous ... op. cit., pp. 35-37; P.F. GIRARD, Manuel élémentaire de droit romain ... op. cit., p. 161 s.urm.

${ }^{96} \mathrm{G}$. MATRINGE, «La puissance paternelle et le mariage des fils et filles de famille en droit romain (Sous I'Empire et en Occident)", Studi in onore di Edoardo Volterra ..., op. cit., p. 198. Din perioada lui lustinian avem următoarele texte : Inst. 1, 10: ... este conform regulii naturii cât și dreptului civil ca acesta, (consimțământul celui sub puterea căruia se află) să fie obținut anterior căsătoriei (t.n.j.d.); Dig. 23, 2, 2, Paulus libro 35 ad edictum „Căsătoria nu se poate realiza dacă nu consimt toți anume cei care se unesc și cei sub a căror putere se află” (t.n.d.j.) Pentru traducerea în franceză: « Les noces ne peuvent se présenter à moins que tous n'y consentent, c'est-à-dire ceux qui s'unissent et ceux sous la puissance desquels ils se trouvent. JUSTINIEN IER EMPEREUR DE BYZANCE, DOMINIQUE GAURIER (trad.): Les 50 Livres du Digeste de l'Empereur Justinien comprennant - pour la première fois en français - La Palingénésie du commentaire sur l'édit du préteur d'Ulpien (d'après Otto Lenel), I - III, Éditions La Mémoire du Droit, Paris, 2017, p. 833. 
, Căsătoria nu poate avea loc fără consimțământul tuturor, adică a celor care se căsătoresc și a celor sub puterea cărora se află. (t.n.d.j. v. aussi: J. GAUDEMET, Droit privé romain ... op. cit., p. 330.) ; Dig. 23, 2, 16, 1 Paulus libro 35 ad edictum; " Dans un discours du divin Marc, il est disposé que, si la fille d'un sénateur avait épousé un affranchi, il n'y aurait pas de noces; un sénatus-consulte à suivi celluici. 1. Son petit-fils prennant une épouse, le fils doit y consentir ; mais, si sa petite-fille se marie, la volonté et l'autorisation de son grand-pèere suffisent. (...) » JUSTINIEN IER EMPEREUR DE BYZANCE, Les 50 Livres du Digeste de l'Empereur Justinien ... op. cit., vol.I, p. 836.

„ Fiul (unui senator) trebuie să consimtă la căsătoria băiatului acestuia, dar când se va căsători fiica acestuia, consimțământul și autorizarea bunicului vor fi suficiente." (t.n.d.j.). Cod 5, 4, 1-2.

97 A se vedea și nota 178 .

98 A se vedea nota 107.

${ }^{99}$ C. FAYER, La familia romana aspetti giuridici ed antiquari Parte seconda Sponsalia, matrimonio, dote ... op. cit., p. 456.

100 Paul.Sent.2.19.2 (a doua parte a textului pare a fi interpolată).Idem. p. 459.

101 Idem. p. 461. Dig.23.2.25.

102 Inst. 1, 10. .

103 A se vedea Dig. 50.16.51. Gaius libro 23 ad edictum provinciale care arată că sub denumirea de parentis trebuiau să fie înțeleși atât tatăl cât și bunicul străbunicul și toți străbunii dar și mama, bunica și străbunica. Cu toate acestea abia cu o constituție din anul 408 se va introduce necesitatea consimțământului mamei la căsătoria copiilor, dar aceasta se va face o dată cu schimbarea opticii asupra necesității consimțământului: de la autoritatea capului de familie, la necesitatea protejării intereselor copilului. P. NoAILlES, Mariage-divorce et restitution de la dot ... op. cit., pp. 207-208.

104 Pentru traducerea în română: : Iustiniani institutiones = Instituțiile lui lustinian, VLADIMIR HANGA ȘI MIRCEA DAN BOB (trad.), Universul Juridic, București, 2009, p. 49.

${ }^{105} \mathrm{G}$. MATRINGE, «La puissance paternelle et le mariage des fils et filles de famille en droit romain (Sous I'Empire et en Occident)", Studi in onore di Edoardo Volterra.

${ }^{106}$ Cod 5. 4. 12. Dig. 23.2.2.

107 Dig. 23.2.16.1.

108 G. MATRINGE, Individualisme et communauté, ..., op. cit.; p. 268.

109 În perioada primară a dreptului roman, prerogativele puterii părintești au fost limitate de mores. Când acestea, au slăbit, o dată cu cuceririle romane, puterea publică va interveni și le va lua locul. Cenzorul până la finalul Republicii și chiar începutul Imperiului, putea controla viața privată alături de cea publică a cetățenilor și putea blama de o manieră eficace capiii de familie care nu urmau un comportament onest. Când această intervenție a devenit insuficientă, dispozițiile imperiale au intervenit și au limitat progresiv puterile lui pater familias asupra copiilor acestuia. v. Idem. G. MATRINGE, "La puissance paternelle et le mariage des fils et filles de famille en droit romain (Sous I'Empire et en Occident)", Studi in onore di Edoardo Volterra ..., op. cit., pp. 193-194. Pentru NoAILLES dispariția unor prerogative ale familiei patriarhale romane, precum dreptul de a-și vinde copiii ori de a-i omorî, nu constituie o schimbare profundă a principiilor familiei romane ci doar dispariția caracterului absolut al prerogativelor lui pater familias. v: P. NoAILLES, Mariage-divorce et restitution de la dot ... op. cit., p. 10. Pentru erodarea prerogativelor a se vedea și GAIUs, Institutes de Gaius contenant le texte et la traduction en regard, avec le commentaire au dessous ... op. cit., pp. 32-33; P.F. GIRARD, Manuel élémentaire de droit romain ... op. cit., p. 152 ș.urm.

${ }^{110} \mathrm{G}$. MATRINGE, "La puissance paternelle et le mariage des fils et filles de famille en droit romain (Sous l'Empire et en Occident)», Studi in onore di Edoardo Volterra ..., op. cit., p. 196. 
111 Idem. p. 195. Autorul utilizează aici „fii și fiice de familie” pentru a desemna nu doar descendenții de gradul I, ci și descendenții în linie dreaptă, cei adoptați sau cei intrați sub patria potestas prin abrogațiune. Idem. p. 196; nota 18. Pentru persoanele care intrau sub patria potestas a se vedea și nota noastră v.: n. 95

112 Dig. 23, 2, 19 Marcianus libro 16 institutionum.

« Dans la chapitre trente-cinq de la Loi Julia, ceux qui ont empêché que les enfants qu'ils ont sous leur puissance prennent des épouses ou se marient, ou qui ne veulent pas donner une dot, à partir de la constitution des divins Sévèere et Antonin, pour les proconsuls et les gouverneurs des provinces, sont contraints en mariage, de les unir et de les doter. Mais est considéré l'empêcher celui qui n'en recherche pas la condition. " v. : (JUSTINIEN IER EMPEREUR DE BYZANCE, Les 50 Livres du Digeste de I'Empereur Justinien ... op. cit., vol.I, p. 836.

${ }^{113}$ Din 736 (18 î. Hr.) v: P.F. GIRARD, Manuel élémentaire de droit romain ... op. cit., p. 169.

114 Pentru detalii asupra dificultății conceptului, precum și pentru traducerea sa prin rea-credință, v: G. MATRINGE, "La puissance paternelle et le mariage des fils et filles de famille en droit romain (Sous I'Empire et en Occident)", Studi in onore di Edoardo Volterra ..., op. cit., p. 204.

115 Textul trimite la o constituție a împăraților Lucius Septimius Severus și a lui Marcus Aurelius Antonius (cunoscut și sub numele de Caracallus) care stabilesc competența proconsulilor ori a praesides que provinciarum. A se vedea, pentru reconstrucția textului: idem. p. 204; n. 56; Castelli GUGLIELLMo: Intorno all'origine dell'obbligo di dotare in dritto romano, în Bullettino dell'istituto di Diritto Romano nr.1913, pp, 164-169.

116 v: Paul MoRIAUD, «Du consentement du père de famille en droit classique» dans, Mélanges $P$. $F$. Girard : études de droit romain dédiées à M. P. F. Girard, professeur de droit romain à I'Université de Paris, à l'occasion du 60e anniversaire de sa naissance (26 octobre 1912), II - II, Paris, Librairie Arthur Rousseau, 1912; C. GUGLIELLMO: Intorno all'origine dell'obbligo di dotare in dritto romano. op. cit; P.F. GIRARD, Manuel élémentaire de droit romain ... op. cit., p. 169. Opinia este împărtășită și de profesorii clujeni: V. HANGA, BOB, M.D., Curs de drept pivat roman ... op. cit. p. 120.

${ }^{117} \mathrm{G}$. MATRINGE, «La puissance paternelle et le mariage des fils et filles de famille en droit romain (Sous I'Empire et en Occident)", Studi in onore di Edoardo Volterra ..., op. cit., p. 199.

118 Idem.

${ }^{119}$ Atunci când pater familias nu se opunea în niciun fel căsătoriei. V. HANGA, BOB, M.D., Curs de drept pivat roman ... op. cit. p. 120. Pentru logodnă Dig. 23, 1, 7. Pentru căsătorie Cod 5, 4, 2; 5, 4, 5.

${ }^{120}$ C. 1.4.25.

121 Pentru etimologia termenului dota a se vedea: C. FAYER, La familia romana aspetti giuridici ed antiquari Parte seconda Sponsalia, matrimonio, dote ... op. cit., p. 673.; pentru cuvântul românesc "zestre" a se vedea: Paul VASILESCU; : Regimuri matrimoniale. Partea generală, Universul Juridic, București, 2009, pp. 131-132.

122 La origini, termenul ar fi însemnat "dar" v.: Paul GIDE; : Du Caractère de la dot en droit romain, par Paul Gide, E. Thorin, Paris, 1872, p. 6. De unde se desprindea idea că nu avea contra-echivalent și nu era nici restituit femeii. Autorul susține în continuare că, dota ar fi servit, până la recunoașterea unui drept de moștenire propriu soției și copiilor acesteia, ca instrument de transmisiune (perpetuă) a averii femeii către copiii acesteia. V: idem. pp. 7-10.

${ }^{123}$ Idem. pp. 3-4.

${ }^{124}$ Nu există dotă acolo unde nu există căsătorie. Dig. 23, 3, 2.

125 P. GIDE, Du Caractère de la dot en droit romain, par Paul Gide ... op. cit., p. 10.

\section{3}


${ }^{126}$ Abia în perioada post clasică, o dată cu un decret al Papei Leon din 458/ 459 d.Hr. dota este identificată ca semn al unui mariaj legitim și se va naște adagiul canonic medieval « II n'y a pas de mariage sans dot » : J. GAUDEMET, Droit privé romain ... op. cit., p. 59; 207.

${ }^{127}$ Pierre NoAILLES; : Répétitions écrites de droit romain approfondi Etude de la dot romaine 1932-1933, Cours de droit, Paris, 1933, p. 57.

128 Idem. p. 58.

129 Idem.

130 Pentru soluțiile identificate pentru asigurarea unei dote, în perioada primară: constituirea ca dotă a cotei succesorale a fetei, sau prin oferirea unui contra echivalent pentru cota sa parte care urma să constituie dota sa, a se vedea: G. MATRINGE, Individualisme et communauté, ..., op. cit.; p. 214 s.urm.

${ }^{131}$ CHARMIDES, cetățean atenian bogat, este plecat într-o căsătorie. El își lasă copiii, o fiică și un fiu, LESBONICUS, în grija unui prieten, MEGARONIDE. LESBONICUS va delapida averea părintească, LYSITELES, prietenul lui LESBONICUS, îi va cere tatălui său, PHILTON să accepte să se căsătorească, fără dotă, cu fiica lui CHARMIDES. Lysiteles îi spune tatălui că, dacă acceptă, „nu îl va costa nimic”. PHILTON îi reproșează: „Să sufăr eu să te văd luând o soție fără dotă?” (15129) La insistența fiului, PHILTON acceptă însă și îi va cere lui LESBONICUS, pe sora sa, pentru LYSITELES, fără dotă. În ciuda prodigalității sale, văzută ca o adevărată depravare morală, LESBONıcus refuză să iși căsătorească sora fără dotă $(15198,15256)$ și vrea să îi dăruiască singurul bun scăpat prodigalității sale. (15205).El nu vrea „ca sora sa să sufere”. Un alt personaj CALLICLES, se va exprima: „Pe Hercule, va fi umilitor ca fata să nu aibă nicio dotă!"(15275) LESBONICUS îi va reproșa lui LYSITELES dorința de a o lua pe sora sa fără dotă. "Să o las în sărăcie ca ea să mă deteste?”(15326) „Nu vreau să se spună peste tot că ți-am dat-o pe sora mea fără dotă, că am făcut-o mai curând concubina decât soția ta. Unde s-ar mai pomeni o așa proastă reputație ca a mea? (15327)

132 În română, piesa este cunoscută ca „Trei bănuți”. Pentru o traducere în franceză, a se vedea: PLAUTE, J. NAUDET; : Théâtre de Plaute. Traduction nouvelle accompagnée de notes, par J. Naudet, Lefèvre, Paris, 1845. Trimiterea la scrierile lui Plaut se datorează lui Éduard Centner, a se vedea : Édouard CENTNER, Droit romain : du Legs, de la dot, et en général de la chose due. Droit français : le Divorce et la séparation de corps en droit international privé, spécialement au point de vue du droit français. (Thèse), Paris, Faculté de droit de Paris, 1893, pp. 4-5.

${ }^{133}$ G. MATRINGE, Individualisme et communauté, ..., op. cit.; p. 232; C. GUGLIELLMO: Intorno all'origine dell'obbligo di dotare in dritto romano. op. cit.

${ }^{134}$ G. MATRINGE, Individualisme et communauté, ..., op. cit.; p. 232; J. GAUDEMET, Droit privé romain ... op. cit., p. 59.

${ }^{135}$ C. FAYER, La familia romana aspetti giuridici ed antiquari Parte seconda Sponsalia, matrimonio, dote ... op. cit., p. 377.

136 P. MORIAUD, "Du consentement du père de famille en droit classique», Mélanges P. F. Girard: études de droit romain dédiées à M. P. F. Girard, professeur de droit romain à I'Université de Paris, à l'occasion du 60e anniversaire de sa naissance (26 octobre 1912); C. GUGLELLMO: Intorno all'origine dell'obbligo di dotare in dritto romano. op. cit.

${ }^{137}$ A se vedea nota 112 .

138 Dig. $37,6,6$. 
${ }^{139}$ Traducerea lui Dominique Gaurier este superioară. „parce qu'un père, à sa fille, doit donner une dot, pour cette raison, une grand-père, à raison de son fils, à sa petite-fille, [doit en donner une]." Justinien IeR empereur de ByZANCE, Dominique GaURIer (trad.): Les 50 Livres du Digeste de l'Empereur Justinien comprennant - pour la première fois en français - La Palingénésie du commentaire sur l'édit du préteur d'Ulpien (d'après Otto Lenel), II - III, Éditions La Mémoire du Droit, Paris, 2017, p. 1533. Hulot traducea diferit textul dându-i un alt înțeles "c'est naturallement au père à doter sa fille, quand l'aïeul fournit cette dot il est censé le faire en consideration de son fils." JUSTINIEN IER EMPEREUR de Byzance, HenRI Hulot (trad.): Les cinquante livres du Digeste ou des Pandectes de l'Empereur Justinien, t. V - VII, Behmer et Lamort (Metz) Rondonneau (Paris), Metz et Paris, 1804, p. 385.

${ }^{140}$ C. GUGLIELLMO: Intorno all'origine dell'obbligo di dotare in dritto romano. op. cit.

${ }^{141}$ Dig. 38.5.1.10.

${ }^{142}$ C. GUGLIELLMO: Intorno all'origine dell'obbligo di dotare in dritto romano. op. cit.

143 Despre infamie a se vedea: Abel Hendy Jones GREENIDGE; : Infamia, its place in Roman public and private law, the Clarendon press, Oxford, 1894; Robert KNAPP, "Legally marginalised groups - the Empire» în PAUL J. DU PLESSIS, ANDO CLIFFORD \& TUORI KAIUS (dir.), The Oxford handbook of Roman law and society, Oxford, Oxford University Press, 2016, pp. 367-368.

${ }_{144}$ Novelle Maj. 6, 9. Apud. G. MATRINGE, Individualisme et communauté, ..., op. cit.; p. 234.

${ }^{145}$ Novele Sev. 1. Apud idem.

146 Idem. Pentru o interpretare în detaliu a Novelei Împăratului Majorian, a se vedea: C. FAYER, La familia romana aspetti giuridici ed antiquari Parte seconda Sponsalia, matrimonio, dote ... op. cit., pp. 618-619.

147 G. MATRINGE, Individualisme et communauté, ..., op. cit.; p. 239.

148 Idem. p. 234; P. NoAlLLes, Etude de la dot romaine ... op. cit., p. 58.

${ }^{149} \operatorname{Cod} 5.12 .14$. unde se arată că o mamă nu poate fi obligată să constituie o dotă fiicei sale, cu excepția unei cauze justificate sau a unei solicitări din partea legii, de unde ar reieși o obligație în sarcina tatălui. Nov. 97.5. unde tatăl este obligat de împărat să constituie o nouă dotă fiicei sale, în vederea unei noi căsătorii.

${ }^{150}$ C.5.27.5.

${ }^{151}$ C.5.27.6.

152 C.5.27.10.

${ }^{153}$ C.5.27.11.

${ }^{154}$ Formalitatea reliefării afecțiunii maritale prin intermediul unei foi dotale va interveni doar în trei cazuri specifice: pasajul de la concubinaj spre o căsătorie legitimă, în vederea legitimării copiilor prin noua căsătorie C.5.27.10. Căsătoria femeilor actrițe și a fiicelor acestora C. FAYER, La familia romana aspetti giuridici ed antiquari Parte seconda Sponsalia, matrimonio, dote ... op. cit., p. 623. și textele citate acolo: C.5.4.23 ; C.5.4.23.3. ; C.1.4.33.2 ; C.5.4.29.6-7. și căsătoria sclavilor eliberați cu un om de condiție liberă în anumite condiții v: C. FAYER, La familia romana aspetti giuridici ed antiquari ... op. cit., pp. 623-624.

155 C.1.5.19.3, C.1.5.12.20.

${ }^{156}$ C.5.11.7.

157 A se vedea nota 149 .

${ }^{158}$ C. FAYER, La familia romana aspetti giuridici ed antiquari Parte seconda Sponsalia, matrimonio, dote ... op. cit., p. 739.

159 Idem.

${ }^{160}$ Idem. p. 741. Nov.35.9. 
161 Idem. Nov.6.9.

162 Idem. p. 748.

${ }^{163}$ C . 5.3.20.3.

${ }^{164}$ C. FAYER, La familia romana aspetti giuridici ed antiquari Parte seconda Sponsalia, matrimonio, dote ... op. cit., p. 749. nota 345. C.5.11.7.2.

165 Dig. 23.2.3; 23.2.9; 23.2.16;

166 (C. 1.4.25.) C. 5.4.25.

167 P. NOAILLES, Mariage-divorce et restitution de la dot ... op. cit., p. 195.

168 C.5.4.25.

169 P. NoAllLes, Mariage-divorce et restitution de la dot ... op. cit., p. 194.

170 lust. Inst. 1.10.

171 Inst. Inst. 1.10.

172 P. NoAllLes, Mariage-divorce et restitution de la dot ... op. cit., p. 194.

173 Idem. p. 195.

${ }^{174}$ Pentru idea reticenței și soluția înlăturării acesteia: Inst. 1, 10. Cu explicație în: J.-L.-E. ORTOLAN, Explication historique des Instituts de l'empereur Justinien ... op. cit., vol.t.ll, pp. 85-86.; Pentru principiu conform căruia nimeni nu putea impune cuiva un succesor, împotriva voinței sale: Inst. 1, 11, 7; J. GAUDEMET, Droit privé romain ... op. cit., p. 44; P.F. GIRARD, Manuel élémentaire de droit romain ... op. cit., p. 169. Aceiași principiu explica motivul pentru care era necesar și consimțământul copilului, la căsătoria nepotului lui pater familias deși în cazul căsătoriei nepoatelor era necesar doar consimțământul lui pater familias. (Dig. 23, 2, 16). Explicația acestui fapt ne ajută să înțelegem reglementările din materia nebuniei. Pater familias avea dreptul să micșoreze numărul persoanelor aflate sub puterea sa, însă el nu putea spori numărul celor ce intrau în familie. Căsătoria fetelor nu prezenta o problemă în acest sens întrucât copiii care se vor fi născut, nu mai aveau o legătură de rudenie agnatică cu rudele de sânge ale fetei, ci intrau în familia soțului lor și sub puterea altui pater familias. În cazul băieților, în schimb, copiii acestora intrau în sânul propriei familiei agnatice, iar la moartea sa, familia trecea în grija unui alt pater familias care se putea trezi cu succesori nedoriți. J. GAUDEMET, Droit privé romain ... op. cit., p. 44; J.-L.-E. ORTOLAN, Explication historique des Instituts de I'empereur Justinien ... op. cit., vol.t.II, pp. 85-86.

175 Dig. 27, 10, 17.

${ }^{176}$ Dig. 42, 8, 25, 1. Textul este preluat din lucrarea despre Interdicte a lui Venuleius Saturnimus. (sec. III d.Hr.). Opinia cuprinsă în text aparține lui Marcus Anttistius Labeo (sec. I D.Hr.). Textul prezintă o soluție în cazul în care dota a fost constituită de tată în frauda creditorilor. Ginerele nu va restitui bunurile creditorilor dacă a ignorat frauda întrucât "cum is indotatam uxorem ducturus non fuerit" (întrucât acesta nu ar fi luat o soție fără dotă (t.n.d.j.)

177 Dig. 23.3.5.3.

178 Dig. 50.16.220 Justinien Ier empereur de ByzAnCE, Les 50 Livres du Digeste de l'Empereur Justinien ... op. cit., vol.III, p. 2394.

179 În celelalte regiuni, de drept cutumiar, cu excepțiile menționate în nota 180, se obișnuia ca viitorul soț să constituie pentru viitoarea soție un douaire (etimologic din latina medievală, dotarium) care devenea adevărata sa dotă. Acest douaire, se pare consta dintr-o sumă de bani sau din anumite bunuri pe care soția le-ar fi primit în uzufruct după moartea bărbatului. Oricum, « il ne se doit point faire de mariage sans dot ", se referea în aceste regiuni, la douaire, iar preoții, la începuturi, nu binecuvântau căsătoria dacă dota nu era constituită. Ch. DAGAR; : Le nouveau Ferrière, ou Dictionnaire de droit et de pratique, civil, commercial, criminel et judiciaire ; contenant l'explication de tous les termes du droit anciens et modernes... par C.-H. Dagar, II - III, I'auteur, Paris, 1804, pp. 5-6. 
180 În regiunile de drept cutumiar, obligația tatălui era una naturală și copiii acestuia nu dispuneau de o acțiune în justiție. Cu toate acestea, o jurisprudență contrară pare să se edifice și aici. Pentru cazul unui judecător avar condamant de Parlement de Paris, la constituirea dotei pentru fiicele sale, jurisprudență preluată apoi de Parlament de Flandre; precum și pentru jurisprudența Grand Conseil de Malines și a Conseil souverain de Brabant care au reținut aceeași obligație de a dota, a se vedea: Philippe-Antoine MERLIN; : Répertoire universel et raisonné de jurisprudence etc., 5e éd., t. IX, H. Tarlier, Libraire-Éditeur, Bruxelles, 1826, pp. 5-6.

181 Idem. p. 3.

${ }^{182}$ Același text pare să fie urmat de mai multe hotărâri ale Parlamentelor regiunilor de drept scris din Franța. Merlin amintește în acest sens o hotărâre a Parlamentului din Toulouse din 13 august 1587, alta din 13 iunie 1612. Și Parlamentul din Bordeaux va lua o decizie similară în 6 aprilie 1604. V: idem.

${ }^{183}$ Toulouse 17 mars 1672 : Journal du Palais, ou recueil des principales décisions de tous les parlemens, et cours souveraines de France, sur les questions les plus importantes de droit civil, de coutume, de matiéres criminelles \& bénéficiales \& de droit public... 4e éd., Tome premier. Contenant les Arrêts depuis l'année 1660, jusqu'en 1678 / par feu Maîtres Claude Blondeau, \& Gabriel Gueret, Avocats en Parlement, Chez David, jeune, libraire, ruë du Hurepoix, près le pont S. Michel, Paris, 1755, p. 189.

${ }^{184}$ P.-A. MERLIN, Répertoire universel et raisonné de jurisprudence. Quatrième édition, corrigée, réduite aux objets dont la connaissance peut encore être utile, et augmentée $1^{\circ}$. d'un grand nombre d'Articles, $2^{\circ}$. de Notes indicatives des changemens apportés aux Lois anciennes par les Lois nouvelles, $3^{\circ}$. de Dissertations, de Plaidoyers et de Réquisitoires de l'éditeur sur les unes et les autres; par M. Merlin,... Tome dix-septième. Additions ... op. cit., vol.t. IX, p. 3.

185 Idem. p. 4.

186 Idem. pp. 4-5.

187 Léon FAYE, René WALDECK-RousSEAU, Emile GIRAUDIAS, Jean-Martial LAHAYE; : Les codes français annotés... I, A. Gobelet, Paris, 1840, p. 37. Pierre-Antoine FENET; : Recueil complet des travaux preparatoires du Code Civil, Ile éd., III - XV, Au depôt, Rue Saint-André-des-Abcs, № 51, Paris, p. 535. unde Tribunal d'appel de Grenoble considera viitorul art. 511 ca recunoscând fetei o acțiune pentru dotă.

${ }^{188}$ Asupra doctrinei franceze care a dezbătut aplicarea acestuia în practică, a se vedea: Charles Marie Barbe Antoine Aubry, Charles Frédéric RaU, Karl Salomo ZaChariä; ; G RaU, Charles Falcimaigne et MAURICE GAULT (sous la dir. de): Cours de droit civil français d'après la méthode de Zachariæ, 5e éd., Marchal et Billard, Paris, 1897, pp. 805-806; Gabriel BAUdRY-LACANTINERIE, Philippe BonNeCARRÈRE, Gustave CHÉNEAUX; : Traité théorique et pratique de droit civil, Des personnes, 3e éd.e éd., IV - V, Société anonyme du 'Recueil Sirey', Paris, 1905, pp. 764-767; Gabriel BAUDRY-LACANTINERIE, Philippe BonneCARRÈRE, Gustave ChÉNEAUX; : Traité théorique et pratique de droit civil, Des personnes, 3e éd.e éd., V-V, Société anonyme du 'Recueil Sirey', Paris, 1908, pp. 826-828; Charles DemolomBE; : [Cours de Code Napoléon]. [VIII], Traité de la minorité, de la tutelle et de l'émancipation : de la majorité : de l'interdiction et du conseil judiciaire : des individus placés dans un établissement public ou privé d'aliénés, 2e éd., VIII (II), coll. "Cours de code Napoléon», Auguste Durand L. Hachette et Cie, libraires, Paris, 1861, pp. 406-410; Claude Etienne DelvincouRT; ; DE ForTBOIS Drault (sous la dir. de): Cours de code civil, II, P.J. de Mat, Bruxelles, 1827, pp. 273-276; François LAURENT; : Principes de droit civil, 4e éd., V - XXXIII, Bruylant-Christophe (Bruxelles); A. Morescq, Ainé et A. Chevalier-Moresq (Paris), Bruxelles; Paris, 1887, pp. 350-356.etc.

189 Revoluția trebuia terminată iar ordinea politică trebuia stabilizată și fixată definitiv părea să fie opinia unanimă a partizanilor complotului lui Bonaparte. v: Jean-François NIORT; : Homo civilis contribution à I'histoire du Code civil français 1804-1965, Presses universitaires d'Aix-Marseille, Aix-en-Provence, 2004, p. 77; parag. 31. 
${ }^{190}$ Codul civil Francez de la 1804 a purtat, la naștere, numele de "Cod civil des Français ». El primește denumirea de "Code Napoleon » odată cu dorința împăratului exprimată în 1806 și cu tiparul ediției din 1807 ce va purta tilul "Code Napoleon édition originale et seuel officielle » (Ediția oficială, la nivel de conținut, va fi cea din 1816, care va renunța al mai menționa pe Napoleon. Ultima ediție oficială, ce purta denumirea de "Cod Napoleon ", va fi cea din 1856 când (doar) se va reveni la denumirea din 1807: "Code civil Napoleon »). Pentru istoricul denumirilor pe care Codul civil francez le-a purtat, a se vedea: idem. p. 24; n. 40.

191 L'Assemblée Législative a invitat printr-o adresă din 16 octombrie 1781 toți cetățenii, chiar și străinii, să comunice puncte de vedere cu privire la formarea unui nou Cod. v: Pierre-Antoine FENET; : Recueil complet des travaux preparatoires du Code Civil, Ile éd., I - XV, Au depôt, Rue Saint-André-des-Abcs, N 51, Paris, p. XXXVI. Pentru motivul eșecului primelor două proiecte, v: idem. p. XLVII. Stefano Solimano este creditat pentru aducerea la lumină a unui alt proiect, al lui Guy Jean-Baptiste Target în lucrarea sa Verso il Code Napoléon. II progetto di codice civile di Guy Bqptiste Target (1798-1799), Giuffré, Milan, 1988 apud : JeanLouis HALPÉRIN, "L'histoire de la fabrication du Code le Code: Napoléon?», Pouvoirs, revue française d'études constitutionnelles et politiques, $n^{\circ} 107,2003$, p. 15; n. 10.

${ }^{192}$ Este vorba despre opiniile solicitate de guvernare, în perioada consulatului, din partea Tribunatului, „Curții de casație” și celorlalte „Curți de Apel” din Franța. v: P.-A. FEnET, Recueil complet des travaux preparatoires du Code Civil ... op. cit., vol.I, p. LXIV. (curțile se numeau la acea dată Tribunal de cassasion și tribunaux d'Appel. v: nota 213). Acestora li se vor adăuga susținerile legilor privind Codul civil din fața Conseil d'État de către reprezentanții guvernării și ai Tribunat-ului. În realitate însă, guvernarea nu va suporta puterea extinsă a Tribunatului.

Constituția din 22 frimaire an VIII slăbește considerabil puterea legislativă. Inițiativa legislativă va aparține guvernării, iar Conseil d'État, auxiliar al consulilor, fără autonomia de a iniția proiecte, va răspunde la solicitările primului consul în vederea redactării legislației necesare.

Tribunat-ul, fără să poată face modificări proiectelor de lege, discuta proiectele propuse de Conseil d'État.. El putea să emită un punct de vedere privind adoptarea sau respingerea acestora în fața Corps Legislatif, care nu putea discuta legile ci doar putea vota, prin vot secret, pe cele discutate în fața sa de către reprezentanții Tribunatului și ai guvernării. Sénat-ul conservateur, avea mai mult un rol formal, dar puterile sale puteau avea urmări grave în raportul cu guvernarea. Aceasta avea atribuții limitate la alegerea membrilor ce compuneau, în principal, Tribunat-ul și Corps Legislatif putând dezbate problemele de neconstituționalitate semnalate doar de Tribunat sau de Gouvernement. v: pentru procedura legislativă: idem. p. LXVI. Pentru textul constituțional: Constitution du 22 frimaire (13.10) 1799 (an VIII); http://www.conseil-constitutionnel.fr/conseilconstitutionnel/francais/la-constitution/les-constitutions-de-la-france/constitution-du-22frimaire-an-viii.5087.html: (7 iunie 2017).

193 Jean-Jacques Régis de CAMBACÉRÈs, 18 oct. 1753-12 martie 1824, originar din Montpellier a fost unul dintre marii contributori ai operei de unificare a dreptului privat francez. Pentru detalii despre viața și activitatea sa, a se vedea Dictionnaire historique des juristes français (XIle-XXe siècle), PATRICK ARABeyre, JeAN-Louis HalpérIn et Jacques Krynen (sous la dir. de), Quadrige/PUF, Paris, 2007.

${ }^{194}$ Datorită contextului politic deosebit de agitat în care au fost discutate și elaborate< v: J.-F. NIORT, Homo civilis contribution à I'histoire du Code civil français 1804-1965 ... op. cit., p. ?

195 Jean-Ignace JACQUEMINOT 14 ian. 1754-13 iun. 1813 în localitatea Naives-Rosières (Meuse), avocat de Nancy este cunoscut pentru două mari proiecte: Le Code Hypothècaire de I'an VII, inspirat de cutumele din nordul Franței și Le projet du Code Civil prezentat între 1799-1800. În ceea ce privește cel de-al doilea, s-a afirmat că proiectul lui JACQUEMINOT este „„însuși Codul civil 1804”.A se vedea : Dictionnaire historique des juristes français (XIIe-XXe siècle), Quadrige/PUF, Paris, 2007, pp. 420421. 
${ }^{196}$ Este vorba despre proiectul redactat de secțiunea legislativă din cadrul Conseil d'État, organism al puterii guvernamentale, instituit o dată cu Consulatul, prin Constituția din 13 decembrie 1799 (22 frimaire an VIII). Misiunea le este încredințată în data de 24 thermidor an VIII (12 august 1800) de către Napoleon Bonaparte, spre a termina proiectul până în ultima decadă a lunii brumaire an IX (final de noiembrie 1800). Proiectul va fi imprimat la 1 pluvoise an IX (21 ianuarie 1801) și discuția primei cărți va avea loc la 4 thermidor an IX în cadrul Consiliului guvernamental. Pentru data exactă a proiectului, a se vedea discuția de la nota 212 .

${ }^{197}$ Arrêté du 24 thermidor an VIII (12 august 1800) în extras în: P.-A. FENET, Recueil complet des travaux preparatoires du Code Civil ... op. cit., vol.I, p. LXII.

198 François Denis TRONCHET: 23 martie 1726-10 martie 1806 este originar din Paris unde urmează cursurile Facultății de Drept. Anul 1800 îl găsește drept președinte al Tribnal de Cassasion. Este privit ca un simbol al vechiului drept, în special al cutumelor Parisului și un promotor al unei ordinii familiale construită împrejurul unei imagini patriarhale. V: Dictionnaire historique des juristes français (XIle-XXe siècle), Quadrige/PUF, Paris, 2007, pp. 752-754.

199 Felix-Julien Jean Bıgot-PrÉAMENENU.

200 Jean-Étienne Marie de PORTALIS.

201 Jacques de MALVEILLE.

202 Afirmația aparține lui MALleVILle citat în: Jean-Étienne-Marie PoRTALIs; FrédérIC PorTALIS (sous la dir. de): Discours, rapports et travaux inédits sur le Code civil publiés par le Vte Frédéric Portalis,... précédé de : Essai sur l'utilité de la codification, Joubert, Paris, 1844, p. XXXVI.

${ }^{203}$ Conform lui Aubry \& Rau, redactorii Codului Civil Napoleon, au dat prioritate regulilor din dreptul cutumiar francez atunci când dreptul cutumiar a admis principii proprii în raport cu dreptul roman. v.: C.M.B.A. AubrY, RAU, C.F., ZAChARIÄ, K.S., Cours de droit civil français d'après la méthode de Zachariæ ... op. cit., p. 36.

204 J.-L. HALPÉRIN, «L'histoire de la fabrication du Code le Code: Napoléon?» ... p. 14.

205 Idem. p. 15.

206 Idem.

${ }^{207}$ A se vedea Error! Reference source not found., analiza viitorului art. 511 din Codul civil Napoleon.

208 Întrucât Jean-Ignace JACQUEMINOT provenea din regiunile de drept cutumiar, fiind născut în Naives și în timpul revoluției fiind deputat din partea departamentului Meurthe cu "capitala" la Nancy, iar reglementarea art. 511 își avea originea în dreptul roman, bizantin. Este adevărat că nu a lucrat singur la proiect, ci a fost ajutat, așa cum afirmă singur, și de alți juriști și cetățeni: FAVARD, GRENIER, Trouchet,. Crassous, Vermeil, Hua, Porriquet, Caurnol și Tardy. Cf : Jean-Ignace Jacqueiminot; : Projet de Code Civil présénte par Jacqueiminot, Député de la Meurthe, A la commision législative du Conseil de Cinq-Cents, Au nom de la Section de Législation, 1799, p. 7.

${ }^{209}$ Al patrulea proiect de Cod, după ce primele trei proiecte, propuse de CAMBACÉRÈs nu au avut succesul preconizat. După ce CAMBACÉRÈs este ales al doilea consul, în anul 1800, îi va reveni lui JACQUEIMINOT sarcina redactării celui de-al patrulea proiect de cod. Acesta se va dovedi incomplet și precipitat și va intra în conflict cu dorința lui Napoleon de a prezida edificarea codului, motiv pentru care nu se va bucura de succes și se va realiza un al cincilea proiect. v : J.-F. NIORT, Homo civilis contribution à l'histoire du Code civil français 1804-1965 ... op. cit., p. 76.

${ }^{210}$ P.-A. FENET, Recueil complet des travaux preparatoires du Code Civil ... op. cit., vol.I, p. 548.

211 Pentru o scurtă observație din partea le Tribunal de Cassassion ce puncta faptul că doar dota și donațiile constituite din bunurile interzisului sunt supuse avizului consiliului de familie, a se vedea: idem vol. II. p. 551.

212 Projet de la Commision de Gouvernément Présenté le 24 thermidor an VIII: art. 52 Titre X De la majorité et de l'interdiction ; Chap. II v : idem. p. 95. Data prezentată de Fenet în volumul II, atunci 
când prezintă proiectul, nu pare să fie însă exactă. Fenet, în introducere, face trimitere la arrét du 24 thermidor an VIII prin care Napoleon setează termenul limită pentru proiect « art. 6 (...) dans la dernière décade de brumaire an IX, et présenté à cette époque aux consuls. " (conform calendarului gregorian, noiembrie 1801). (idem vol. I. p. LXIII.) Pentru detalii, a se vedea și : J.-F. NIORT, Homo civilis contribution à l'histoire du Code civil français 1804-1965 ... op. cit., pp. 45-46. (n. 86).

${ }^{213}$ Aici, termenul tribunal este propriu perioadei revoluționare. Instituțiile își vor schimba denumirea în Cour de Cassasion și Cours d'Appels o dată cu instituirea primului Imperiu (1804-1814) v: J.-F. NIORT, Homo civilis contribution à l'histoire du Code civil français 1804-1965 ... op. cit., p. 81; nota 96. Această schimbare are loc prin Sénatus-consultus organique du 18 mai 1804, Titre XIV De l'ordre judiciaire, art. 136. v: Sénatus-consulte organique du 28 mai 1804; http://www.culture.gouv.fr/Wave/ image/web/archim/?ref=AF-02938: (1 juin 2017).

${ }^{214}$ Relevante în acest sens sunt discuțiile purtate în cadrul ședințelor din 28 messidor an IX, 4 thermidor an IX, 6 thermidor an IX, 24 brumaire an X. A se vedea: P.-A. FENET, Recueil complet des travaux preparatoires du Code Civil ... op. cit., vol.I, pp. LXVIII - LXXVII. Numerotarea finală a Codului are loc în ședințele din 17 și 26 ventose an XII. Idem. pp. LXXX, LXXXVIII.

215 Idem. pp. 527-462.

216 Idem vol. X. p. 681 ș.urm.

217 Întregul titlu va fi dezbătut în ședințele din 13 brumaire an XI- 4 noiembrie 1802, 20 brumaire an XI- 11 noiembrie 1802 și 4 frimaire an XI - 25 noiembrie 1802.

218 „Familia nu trebuie convocată decât pentru a da un aviz, supus mai apoi tribunalului. Fără această precauție, copiii ar putea abuza de dispoziția stabilită de către acest articol” (t.n.d.j.) v. :P.-A. FENET, Recueil complet des travaux preparatoires du Code Civil ... op. cit., vol.X, p. 695.

${ }^{219}$ Idem. p. 696.

220 Idem. p. 706.

${ }^{221}$ Idem. p. 695.

222 Emmery v: idem. p. 713.

${ }^{223}$ Idem. pp. 727-728. Pentru aceleași idei. Jean-Guillaume LocRÉ; : Esprit du Code Napoléon ; tiré de la discussion, ou, Conférence historique, analytique et raisonnée du projet de Code civil, des observations des tribunaux, des procès-verbaux du Conseil d'état, des observations du tribunat, des exposés de motifs, des rapports et discours, \&c., \&c.;, vol. III (t. IV et V), Imprimerie Imperiale, Paris, 1807, pp. 371-372.

„După ce s-a preocupat să protejeze prea importantele și scumpele interese ale interzisului, proiectul de lege și-a răsfrâns solicitudinea asupra copiilor acestuia. Este deja prea mare pentru ei povara impusă tandreții și sensibilității lor; nu trebuie ca ei să rămână victime ale umilitoarei și penibilei stări a tatălui lor, trebuie să li se faciliteze mijloacele prin care să se stabilească, trebuie așadar ca o autoritate binevoitoare și legală să înlocuiască, pe cât este posibil, afecțiunea și generozitatea unui tată ce nu mai poate fi consultat, întrucât nu mai are voință. De acum încolo, consiliul de familie va veni, și în acest caz, va interpune autoritatea sa oficioasă. El reglează dota, avantajele și toate celelalte convenții matrimoniale, dar această activitate este supusă controlului procurorului imperial și omologării tribunalului, care se asigură înainte de a o acorda, că sacrificiile pe care le solicităm tatălui sunt fondate pe averea sa, că nu sunt exorbitante, precum a absorbi cheltuielile necesare antrenate de tenacitatea maladiei de care acesta suferă." (t.n.d.j.)

${ }^{224}$ P.-A. FENET, Recueil complet des travaux preparatoires du Code Civil ... op. cit., vol.X, pp. 745-746. 